\title{
QAGUPUBLICATIONS
}

Water Resources Research

\section{Stable and Radioisotope Systematics Reveal Fossil Water as Fundamental Characteristic of Arid Orogenic-Scale Groundwater Systems}

\author{
Brendan J. Moran (ORCID = 0000-0002-9862-6241) $)^{1}$, David F. Boutt $($ ORCID = 0000- \\ 0003-1397-0279) $)^{1}$, Lee Ann Munk $\left(\right.$ ORCID =0000-0003-2850-545X) ${ }^{2}$ \\ ${ }^{1}$ Department of Geosciences, University of Massachusetts-Amherst, Amherst, MA, USA \\ 2 Department of Geological Sciences, 3101 Science Circle, University of Alaska- \\ Anchorage, Anchorage, AK, USA \\ Corresponding author: Brendan J. Moran (bmoran@geo.umass.edu)
}

\section{Key points}

- Analysis of tritium in water discharging within Salar de Atacama basin show it is composed predominantly of water $>60$ years old.

- Water entering the Salar de Atacama basin is spatially distinct and decoupled from recharge on the Altiplano-Puna plateau.

- Analysis of stable $\mathrm{O}$ and $\mathrm{H}$ isotope ratios in 900 water samples constrain the spatiotemporal dimensions of modern and fossil groundwaters.

Keywords: Salar de Atacama, Chile; paleo-recharge; Tritium; Altiplano-Puna plateau; regional groundwater flow 


\section{Abstract}

In arid and semi-arid regions, persistent hydrological imbalances illuminate the considerable gaps in our spatiotemporal understanding of fundamental catchment-scale governing mechanisms. The Salar de Atacama basin is the most extreme example of groundwaterdominated continental basins and therefore is an ideal place to probe these unresolved questions. Geochemical and hydrophysical observations indicate that groundwaters discharging into the basin reflect a large regional system integrated over $10^{2}-10^{4}$ year time-scales. The groundwater here, as in other arid regions is a critical freshwater resource subject to substantial demand from competing interests, particularly as development of its world-class lithium brine deposit expands.

41 Utilizing a uniquely large and comprehensive set of $\mathrm{H}$ and $\mathrm{O}$ isotopes in water we demonstrate that much of the presumed recharge area on the Altiplano-Puna plateau exhibits isotopic signatures quite distinct from waters presently discharging within the endorheic Salar de Atacama watershed. $\delta^{18} \mathrm{O}$ values of predicted inflow source waters are $3.6 \%$ to $5.6 \%$ higher than modern plateau waters and ${ }^{3} \mathrm{H}$ data from 87 discrete samples indicate nearly all of this inflow is composed of pre-modern recharge (i.e. fossil water). Under plausible conditions, these distinctions cannot be explained solely by natural variability in modern meteoric inputs or by steady-state groundwater flow. We present a conceptual model revealing the extensive influence of transient draining of fossil groundwater storage augmented by regional interbasin flow from the Andes. Our analysis provides robust constraints on fundamental mechanisms governing this arid continental groundwater system and a framework within which to address persistent uncertainties in similar systems worldwide.

\section{Plain Language Summary}

Groundwater in the driest places on Earth is a vital resource for both humans and ecosystems, yet fundamental characteristics of this water such as where it originates and how it moves in the ground remain unresolved. This water often lies deep underground and flows across great distances and over long periods of time, as a result, it is quite difficult to study. Using the 1000 water samples in the Salar de Atacama basin in northern Chile at the border of the driest desert on Earth we trace the origin and travel time of water across a large region. Groundwater in the Salar de Atacama region is fundamental to sustaining natural and human systems, therefore, developing a better understanding of how this water moves will be critical for their management,

62 particularly as development of its world-class lithium brine deposit expands. We find that 'fossil

63 water' which entered the ground hundreds or thousands of years ago makes up most of the water 64 now flowing into the basin. Our analysis also defines the area which contributes water to the 65 basin, much of which incorporates flow through mountains and from other higher elevation 
Manuscript submitted for Review in Water Resources Research - September 19, 2019

basins. By improving our understanding of how these large flow systems develop and function this work will aid efforts to sustainably manage these critical freshwater resources for all who rely on them.

\section{Introduction}

In the driest places on Earth, internally drained basins of various scales exhibit groundwater discharge rates that exceed modern recharge (Gleeson et al., 2012; Scanlon et al., 2006; Van Beek et al., 2011). These hydrologic budget imbalances have been observed or inferred in nearly every arid region including: the southwestern United States (Belcher et al., 2009; Kafri et al., 2012, Love et al., 2018; Wheater et al., 2007), the Himalayan-Tibetan plateau (Ge et al., 2016 and references therein), central Australia (Skrzypek et al., 2016; Wood et al., 2015), the Sahara desert (Gasse et al, 2000; Kröpelin et al., 2008), the Arabian peninsula (Burg et al. 2013; Müller et al., 2016; Wheater et al., 2007) and the central Andes (Corenthal et al., 2016 and references therein). Difficulty constraining fundamental hydrological processes such as response times, flow paths and distribution and timing of groundwater recharge is magnified by long residence times $(>1 \mathrm{ka})$, deep water tables $(>100 \mathrm{~m})$ and often insufficient data (Favreau et al., 2009; Gleeson et al., 2011; Walvoord et al., 2002). Uncertainties among inputs are compounded by equally large uncertainties in discharge, which in these endorheic systems occurs exclusively through evapotranspiration (Kampf \& Tyler, 2006; Tyler et al., 1997). Fundamental uncertainties have perpetuated inconsistencies in our conceptual models of system-wide groundwater flow and the spatiotemporal dimensions of this flow, as a result, it is clear that current conceptual models need to be adjusted or altogether re-evaluated (e.g. Currell et al., 2016; Haitjema \& Mitchell-Bruker, 2005).

In the Preandean Depression, a large intramontane depression on the margin of the hyperarid core of the Atacama Desert and the Central Andean Plateau, it has been shown that water and solute budgets are difficult to close under currently accepted catchment dimensions (Figure 1). In the Río Loa watershed to the north (i.e. Calama Basin), anomalous water discharge volumes have been observed (e.g., Jordan et al., 2015) and the Central Depression to the west has anomalous nitrate accumulation (Pérez-Fodich et al., 2014). The most prominent feature in the region, the Salar de Atacama basin is defined by very large elevation and precipitation gradients which have led to the development of an orogenic-scale groundwater system encompassing portions of the adjacent Altiplano-Puna plateau. Recent work has concluded that solute and water influxes to Salar de Atacama would need to be 9-20 times greater than modern to account for the massive 


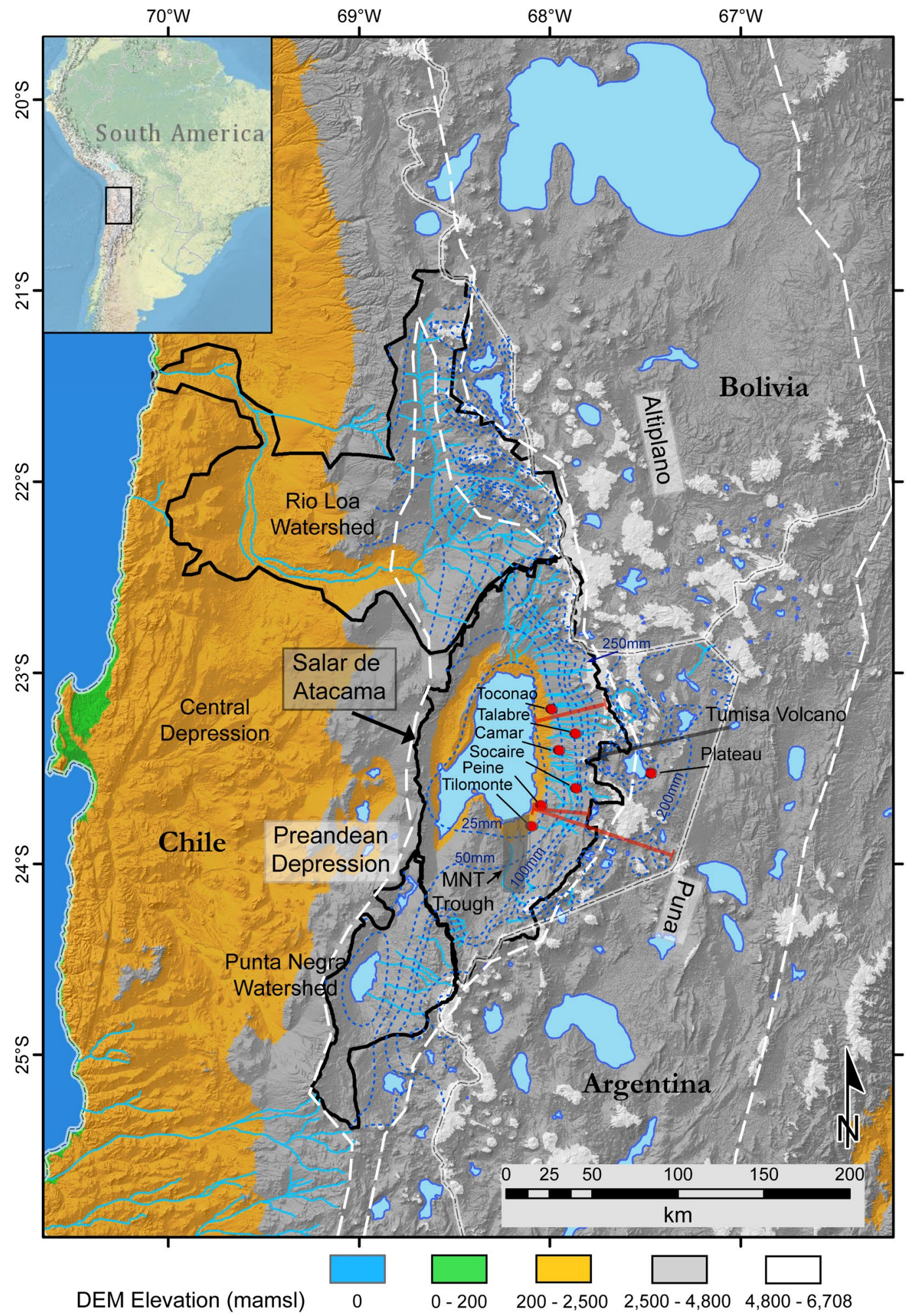

Figure 1. Digital elevation map of the Central Andes. Salars, lagoons and major drainages (quebradas and rivers) are light blue. Topographic watersheds of major basins are outlined in black. Extent of the Preandean Depression and Altiplano-Puna plateau are outlined in white dashes. Isohyetal contours in $\mathrm{mm} /$ year are dark blue dashed lines. Locations of generalized geologic cross-sections in Figure S1 are red. Red dots are precipitation gauges and sites used for HYSPLIT models. MNT Trough structure is shaded. 
evaporite deposit accumulated there since the Miocene (Boutt et al., 2018; Corenthal et al., 2016), but also that it is possible to accumulate the Li deposit from low-temperature weathering within a reasonable timeframe (Munk et al., 2018). Fundamental aspects of subsurface fluid flow remain

103 unresolved including (i) catchment-wide response times to changes in recharge and water tables,

104 (ii) spatial and temporal connections between the modern and paleo-hydrological systems, and

105 (iii) the sources of additional water and solutes required to balance mass at various scales. The

106 Salar de Atacama basin and its larger groundwater system is an ideal place to methodically

107 address these questions; this work advances our understanding of each.

The hydrogeologic system of Salar de Atacama ranks as the most extreme on Earth; on

109 the margin of the driest non-polar desert and flanked by one of the highest and broadest plateaus

110 (Hartley \& Chong, 2002). These extreme conditions, persistent for at least $7 \mathrm{Ma}$, longer than any

111 other place on the planet (Jordan et al., 2002; Rech et al., 2019) have produced its hydrological

112 characteristics. The near total lack of vegetation and surface water other than where groundwater

113 meets the surface, coupled with large precipitation and topographic gradients allow for

114 identification and delineation of distinct groundwater systematics. Accordingly, large-scale

115 governing mechanisms are also magnified and easily characterized and constrained. The

116 combined effect of these characteristics allows fundamental properties of the system to be

117 accurately interpreted within an integrated region-wide analysis.

118 We utilize a novel and comprehensive dataset of $\sim 1000$ individual water samples 119 covering approximately $28000 \mathrm{~km}^{2}$ to identify 'fossil water' (defined herein as water which 120 entered the ground prior to 60 years ago) currently manifest in this system and define how it 121 interacts with the modern hydrologic regime. Analysis of oxygen $\left({ }^{18} \mathrm{O} /{ }^{16} \mathrm{O}\right)$ and hydrogen $\left({ }^{2} \mathrm{H} /{ }^{1} \mathrm{H}\right)$

122 isotope ratios show inflows within the basin from springs and diffuse groundwaters have a 123 consistently higher $\delta^{18} \mathrm{O}$ and $\delta^{2} \mathrm{H}$ signatures relative to presumed source waters revealing 124 important distinctions among inflow and recharge waters. Tritium $\left({ }^{3} \mathrm{H}\right)$ content in 87 discrete 125 inflow waters are almost entirely ${ }^{3} \mathrm{H}$-dead, defining a pronounced disconnect between modern 126 inputs and groundwater region-wide. These results coupled with hydrophysical, geological and 127 atmospheric data suggest that large portions of the adjacent plateau are not hydraulically 128 connected to shallow groundwaters presently discharging into the Salar de Atacama basin and 129 modern ( $<60$ years), local meteoric inputs to the system are limited. We present an integrated 130 conceptual model demonstrating that steady-state assumptions are inadequate, watershed 131 boundaries must be redefined and transient head-decay of groundwater storage over thousand132 year time scales is a critical component of the present hydrogeologic system. 
Manuscript submitted for Review in Water Resources Research - September 19, 2019

\section{Hydrogeologic Setting}

Endorheic basins are topographically closed with a negative annual water balance, these systems often develop salars (salt pans) at their floors (Eugster, 1980; Rosen, 1994). Local flow paths mimic topography and occur between adjacent higher and lower elevation zones, while regional flow paths may cross topographic boundaries (Haitjema \& Mitchell-Bruker, 2005; Tóth, 1963). Typical of other mountainous arid regions, the Salar de Atacama basin can be divided into high elevation areas where most recharge occurs, a zone of lateral fluid flow and a discharge area near the basin floor (Maxey, 1968). High vertical relief and precipitation gradients have contributed to the development of an extensive regional groundwater flow system.

The Salar de Atacama basin coincides with a sharp bend in the modern Andean volcanic arc which retreats $60 \mathrm{~km}$ east from its regional N-S trend (Reutter et al., 2006) (Figure 1). The salar at its floor covers $3000 \mathrm{~km}^{2}$ at 2300 mamsl and is flanked by the Andean Cordillera ( $\sim 5500$ mamsl) to the north, south, and east and by the Cordillera de Domeyko ( $\sim 3500$ mamsl) to the west. Its topographic watershed encompasses $17000 \mathrm{~km}^{2}$, divided to the east and southeast by several high volcanic peaks (Figure 1) which form the western margin of the Altiplano-Puna plateau, a broad expanse of volcanic peaks and basins between 4000 mamsl and 6000 mamsl (Allmendinger et al., 1997; Jordan et al., 2010). It consists of a succession of volcanic units deposited during the last $10 \mathrm{Ma}$ by large caldera-forming eruptions, small volume mafic centers and numerous stratovolcanoes (Strecker et al., 2007; Ward et al., 2014). These volcaniclastic deposits have relatively high permeability (Gardeweg \& Ramirez, 1987; WMC, 2007).

Numerous Miocene ignimbrites draped across the region and alluvial fans along the flanks of the Salar de Atacama basin are important controls on springs and diffuse inflows at the margin of the basin floor (Jordan et al., 2002; Mather \& Hartley, 2005) (Figure S1). The fractured unwelded and moderately welded ignimbrites exhibit high infiltration capacity and permeability providing major flow paths for local and regional groundwater, while welded ignimbrites may act as confining units (Herrera et al., 2016; Houston, 2009). Large clastic deposits, many of Miocene age and buried alluvial fans such as those near the topographic divide and along the salar margins provide substantial storage capacity and are conduits for deep groundwater transport within the eastern slopes of the basin (Houston, 2009; Wilson \& Guan, 2004) (Figure S1).

The eastern margin of the basin contains several sub-watersheds delineated by a $60 \mathrm{~km}$ long $\mathrm{N}-\mathrm{S}$ oriented trough in the south called the Monturaqui-Negrillar-Tilopozo (MNT); the Miscanti fault and fold system to the east separates the basin from the Andes and controls the 


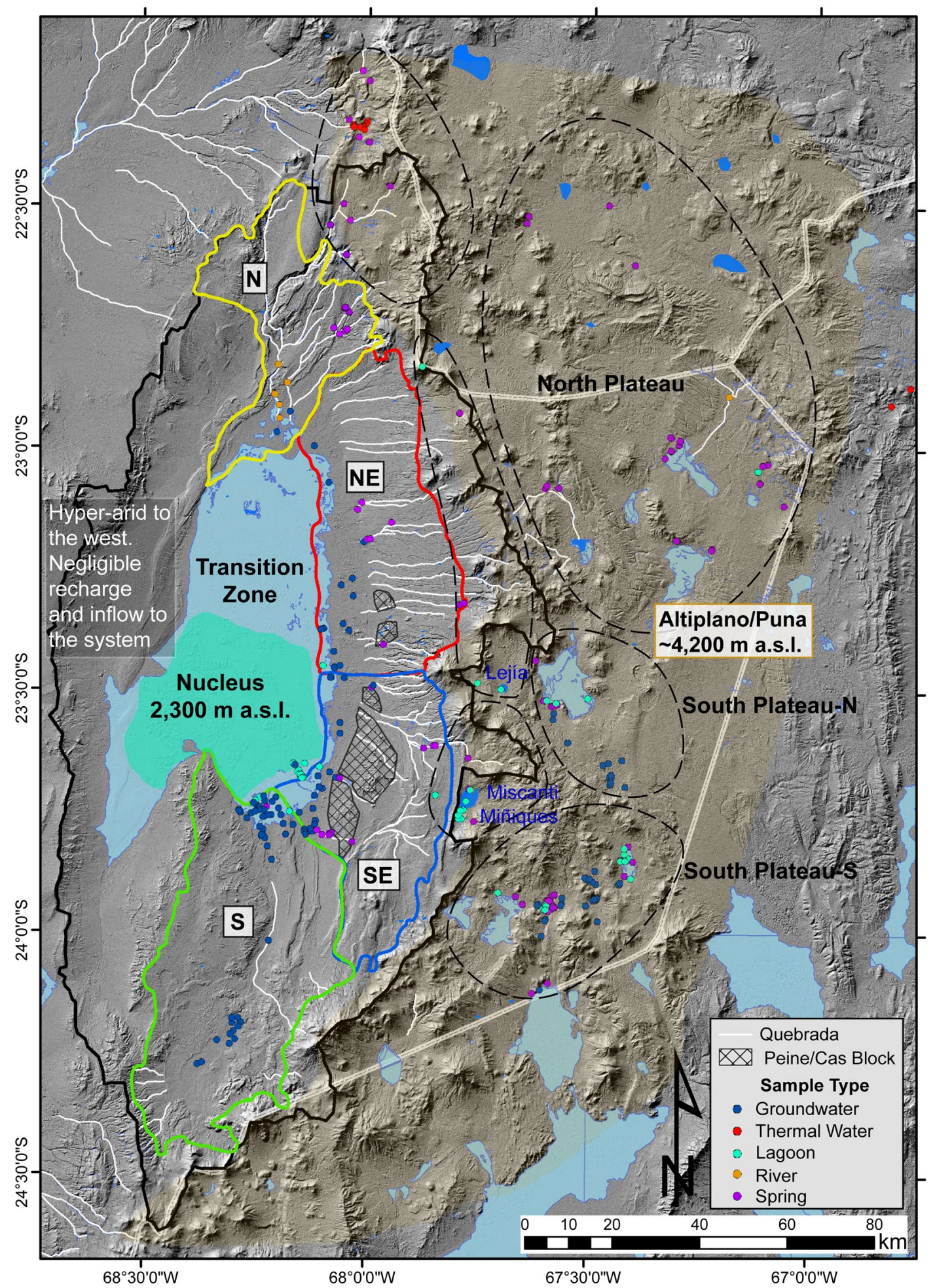

Figure 2. The Salar de Atacama topographic watershed (solid black line), its recharge zones (black dashed ellipses) and discharge/inflow zones (solid colored lines). Dots represent sample sites, grouped by water type. Discharge zones extend from the salar margin to 4000 mamsl. Major drainages (quebradas and rivers) are shown in white and salars and lagoons in light blue and dark blue respectively. Notable high elevation lagoons Miñiques, Miscanti and Lejía are labeled. Surface expression of the Peine/Cas structure is hatched. 
Manuscript submitted for Review in Water Resources Research - September 19, 2019

development of the intra-arc lakes Miñiques and Miscanti and the broad Tumisa volcano divides the northeast from the southeast sub-watersheds (Aron et al., 2008; Rissmann et al., 2015) (Figure $1 \&$ S1). A large Paleozoic structural block (Peine/Cas block), bounded by the N-S trending Toloncha fault and fold system and Peine fault is interposed in the center of the southeastern slope forming a major hydrogeologic obstruction that diverts, restricts and focuses groundwater flow through this zone (Aron et al., 2008; Boutt et al., 2018; Breitkreuz, 1995; Gonzalez et al., 2009; Jordan et al., 2002; Ruetter et al., 2006) (Figure 2). The N-S fold and thrust belt architecture of the basin slope forms several fault systems of varying extent and depth parallel to the salar margin; these and associated lower-order faults are thought to be major conduits for groundwater flow to the surface as evidenced by the spring complexes emerging along or in the vicinity of these zones (Jordan et al., 2002).

The extreme aridity here is a result of subsiding air within the subtropical high-pressure zone, the presence of the cold Humboldt current off the Pacific coast and the Andean Cordillera acting as a high orographic barrier to precipitation from the east (Garreaud et al., 2003; Hartley \& Chong, 2002). Rainfall varies significantly annually but on average the majority of precipitation falls during the Austral summer and La Niña episodes (Houston, 2006a; Magilligan et al., 2008). Within the watershed and on the plateau, there are strong orographic effects on precipitation. Annual precipitation at the basin floor averages only $15 \mathrm{~mm} /$ year while many areas over 4500 mamsl within the topographic watershed average about $250 \mathrm{~mm} /$ year (DGA, 2013; Houston, 2006b). Of this high-altitude precipitation, approximately 50 to $80 \mathrm{~mm}$ of snow water equivalent falls each year above 4500 mamsl, however much of this liquid sublimates due to high insolation and low relative humidity (DGA, 2013; Vuille \& Ammann, 1997). There is no permanent ice at present and it is likely that there was no glaciation in this portion of the Andes even at the highest altitudes (Ammann, et al., 2001; Ward et al., 2015).

Paleoclimate records indicate that hyper-arid conditions dominated prior to $325 \mathrm{ka}$ in this region but that a more variable climate has existed since, especially during the most recent glacial cycle (Bobst et al., 2001; Lowenstein et al., 2003). During the Central Andean Pluvial Event from about 18-8 ka, altiplano lake levels increased by tens of meters (Blard et al., 2011; Blodgett et al., 1997; Fritz et al., 2004; Placzek et al., 2006, 2009, 2013; Sáez et al., 2016), and a smaller amplitude but substantial wet phase occurred around 4-5 ka (De Porras et al., 2017; Rech et al., 2003). Sediment cores, rodent middens and paleo-wetland records indicate that during the Holocene the climate was somewhat wetter until about $3 \mathrm{ka}$ when it shifted to its modern regime (Betancourt et al., 2000; Bobst et al., 2001; Latorre et al., 2003; Quade et al., 2008; Rech et al., 2002). Laguna Lejía approximately $40 \mathrm{~km}$ east of the salar at 4325 mamsl at its late-glacial high 
Manuscript submitted for Review in Water Resources Research - September 19, 2019

201

202

203

204

205

206

207

208

209

210

211

212

213

214

215

216

stage was $\sim 25 \mathrm{~m}$ higher than today which would require double the modern precipitation rate, up to $500 \mathrm{~mm} /$ year (Grosjean et al., 1995; Grosjean \& Núñez, 1994).

\section{Methods}

\subsection{Water Tracer Data}

Surface and groundwater samples analyzed for this study were collected during numerous field campaigns between October 2011 and December 2017. In addition, we utilized all available published data and reports to supplement our dataset (Table S1). Samples were collected with a consistent, standardized procedure and when possible, seasonally from the same location. All samples were filtered through a 0.45 -micron filter and groundwater samples were extracted from wells screened at or below the water table with a peristaltic pump through clean polyethylene tubing or with a clean bailer. In-situ measurements of temperature, specific conductance, and $\mathrm{pH}$ were made at each sampling location during collection. Locations of all stable and radioisotope samples are presented in Figure 2, a detailed analytical procedure for these analyses is provided in supplemental material (Text S2).

\subsection{Discharge Zones, Recharge Zones and Water Types}

Sub-watersheds (zones of inflow) to the Salar de Atacama basin, designated N, NE, SE and $\mathrm{S}$ were defined by topography, hydrogeology and isotopic characteristics (Figure 2). All shallow ( $<120 \mathrm{mbgl}$ ) inflow entering the basin is divided into these discrete zones corresponding closely to the "watershed regions" and "groundwater flux basins" defined by Munk et al. (2018). Explicit boundaries at the margins of these zones were defined by groundwater contouring and flow directions determined from groundwater level measurements in the field. At high elevation, six groundwater recharge zones were delineated based on topography and orientation relative to the Salar de Atacama watershed. Three of these zones straddle the watershed divide where hydrologic conditions are distinct from the plateau further east. This facilitates a detailed spatiotemporal analysis of water isotope signatures among recharge and discharge waters allows for an examination of sources and flow paths and ultimately to constrain dominant hydrological mechanisms within and between these zones.

All data were categorized into six water types (Groundwater, Spring, Spring-fed River, River, Lagoon, and Thermal) designed to facilitate inter-comparison and interpretation of results. Almost no vegetation exists except where freshwater bodies intersect the surface, consequently, these water classifications were reliably determined with the use of satellite imagery and field 
Manuscript submitted for Review in Water Resources Research - September 19, 2019

observations. Groundwater is herein defined as samples taken directly from wells (e.g. monitoring, pumping) that are open to the aquifer at depths ranging from 1 to $\sim 120 \mathrm{mbgl}$. Spring water denotes perennially flowing groundwater discharge and Spring-fed Rivers are waters fed predominantly by groundwater discharge a short distance $(<1 \mathrm{~km})$ upgradient of where it was sampled. These waters are herein grouped with Spring waters because our analysis shows them to be isotopically indistinguishable. Rivers are defined as large systems of perennially flowing surface waters $>10 \mathrm{~km}$ in length. Lagoons are surface water that is perennially extant at the surface, including freshwater lakes, wetlands, and brackish-to-salt lagoons. Thermal waters are from geysers or thermal pools directly influenced by geothermal heat with temperatures between $\sim 40^{\circ}$ to $\sim 80^{\circ} \mathrm{C}$. The distinction between these water types is based on extensive knowledge of the regional hydrogeology gathered during more than ten field campaigns, previous published work and scrutiny of isotopic signatures.

\subsection{Atmospheric Back-Trajectory Modelling}

To constrain prevailing atmospheric moisture sources in the modern climate system we calculated 5-day air parcel back-trajectories using NOAA Air Resources Laboratory's HYSPLIT Transport and Dispersion Model for all large and extensive precipitation events in the region over the past 20 years (1997-2017) (DGA, 2013; Draxler \& Hess, 1998). More detail is provided in supplementary material (Text S2).

\section{Results}

\subsection{Tritium}

Our exhaustive set of water samples from the Salar de Atacama watershed were analyzed for ${ }^{3} \mathrm{H}$ isotope content of the water molecules, these ${ }^{3} \mathrm{H}$ values are used as a direct tracer of Mean Residence Time (MRT) and source (Table S1). We determine a "percent modern water" $\left(\mathrm{R}_{\mathrm{mod}}\right)$ in these samples not as a direct estimate of the modern water content but rather as a relative value to compare connections with modern meteoric inputs. To determine $\mathrm{R}_{\bmod }$ we first constrain the average ${ }^{3} \mathrm{H}$ content of modern precipitation in the region. This value, also presented by Boutt et al. (2016) was determined to be $3.23 \pm 0.6 \mathrm{TU}(1 \sigma)$ from five carefully chosen rain samples collected during 2013 and 2014 (locations in Figure 3). This agrees with the range of values from Cortecci et al. (2005), Grosjean et al. (1995), Herrera et al. (2016) and Houston (2002, 2007). We use a value on the lower end of the published range (3.23TU) based on the assumption that smaller precipitation events are unlikely to produce actual recharge in this environment and events with the lowest tritium values (sourced from the Pacific Ocean) are reflective of decade- 


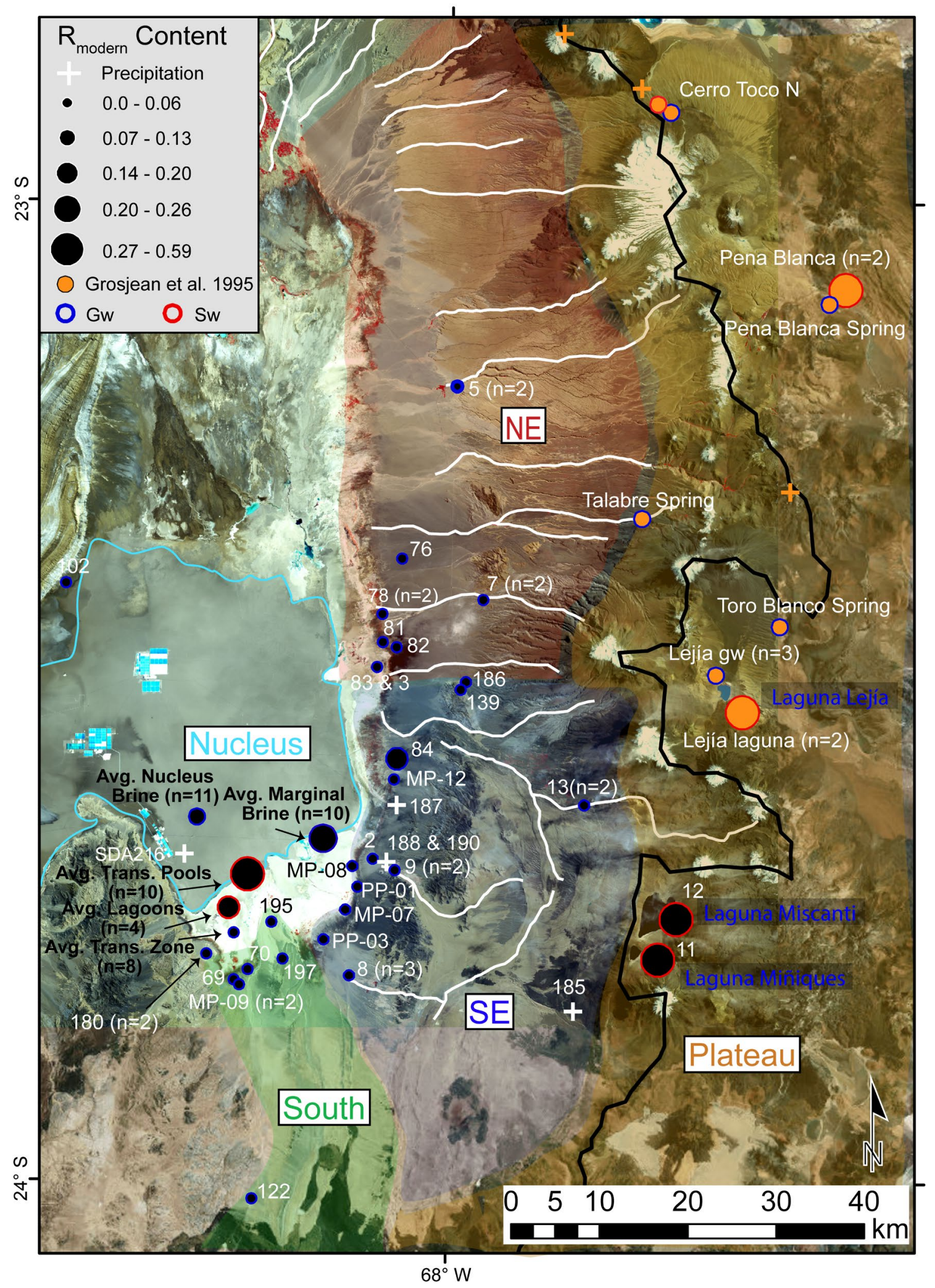

Figure 3. Modern water content in samples $(n=87)$ proportional to circle size. Shaded areas are inflow water zones. Data from Grosjean et al. (1995) are orange. Circles in Nucleus and Transition Zone represent averages of water bodies. Surface waters (sw) are outlined in red, groundwaters (gw) in blue. 
scale bias from ENSO conditions not the average (Houston, 2007). We assume this meteoric input value is representative of average precipitation from about 1990 to present because the bomb peak signature is no longer resolvable after that date in the southern hemisphere, and also representative of average precipitation before the mid-1950's since the bomb peak had not yet occurred (Houston, 2007; Jasechko, 2016). Water recharged in 1955 prior to the bomb peak with

$270 \mathrm{a}{ }^{3} \mathrm{H}$ content of $3.23 \pm 0.6 \mathrm{TU}$ would have between 0.08 and $0.11 \mathrm{TU}$ in July 2018 (Stewart et al., 271 2017).

This pre and post-bomb background ${ }^{3} \mathrm{H}$ production temporally constrains the meteoric

273 input value, but there is also a potential source of ${ }^{3} \mathrm{H}$ that is produced within the aquifer from ${ }^{6} \mathrm{Li}$

274 neutron flux. This potential in-situ production from water-rock interaction is generally assumed

275 to be very small but given the Li-rich aquifer material in this region we consider it a potential

276 factor in the maximum apparent background ${ }^{3} \mathrm{H}$ threshold (Boutt et al., 2016; Houston, 2007).

277 By assessing the ${ }^{3} \mathrm{H}$ content of Salar de Atacama nucleus brine samples which have been

278 determined to be $>>60$ years old through other methods, we can establish the cutoff for this in

279 situ production to be approximately 0.15 TU (Boutt et al., 2016; Houston, 2007; Munk et al.,

280 2018). Therefore, values less than $0.15 \mathrm{TU}$ are essentially indistinguishable from $0.0 \mathrm{TU}$ due to

281 this potential in situ production in waters containing effectively zero water volume recharged

282 post-1955; waters below this threshold are interpreted to be ${ }^{3} \mathrm{H}-$ dead. Nearly all waters sampled

283 in this analysis contain values of ${ }^{3} \mathrm{H}$ near zero and therefore contain small fractions of modern

284 water if any; because of this, our objective is not to directly estimate discrete MRT distributions

285 or the "percent modern" component of these waters (Cartwright et al., 2017). Instead, we

286 quantify the relative amount of modern water present to constrain connections to modern

287 meteoric inputs among the surface and groundwater bodies and connections between these 288 systems.

All ${ }^{3} \mathrm{H}$ samples are allocated to nine distinct water "bodies" representing the major water 290 compartments in the basin. These groundwater and surface water bodies, corresponding closely 291 to those discussed by Boutt et al. (2016) and Munk et al. (2018) are hydrogeologically distinct, 292 formed and sustained by a unique set of hydrological processes. Waters are grouped into (Figure 293 3): Nucleus Brines, a very dense brine ( $>200 \mathrm{mS} / \mathrm{cm} \mathrm{SC}$ ) within the core of the evaporite aquifer; 294 Marginal Brines, a dense brine in the transition between the Nucleus Brines and fresher 295 Transition Zone waters; the Transitional Pools, highly saline ( $>200 \mathrm{mS} / \mathrm{cm} \mathrm{SC})$ surface waters at 296 the margin of the nucleus surficial halite deposit, in the southeast zone of the salar these waters 297 occupy about $0.2 \mathrm{~km}^{2}$ of surface area. Landward of these Transitional Pools are several large 


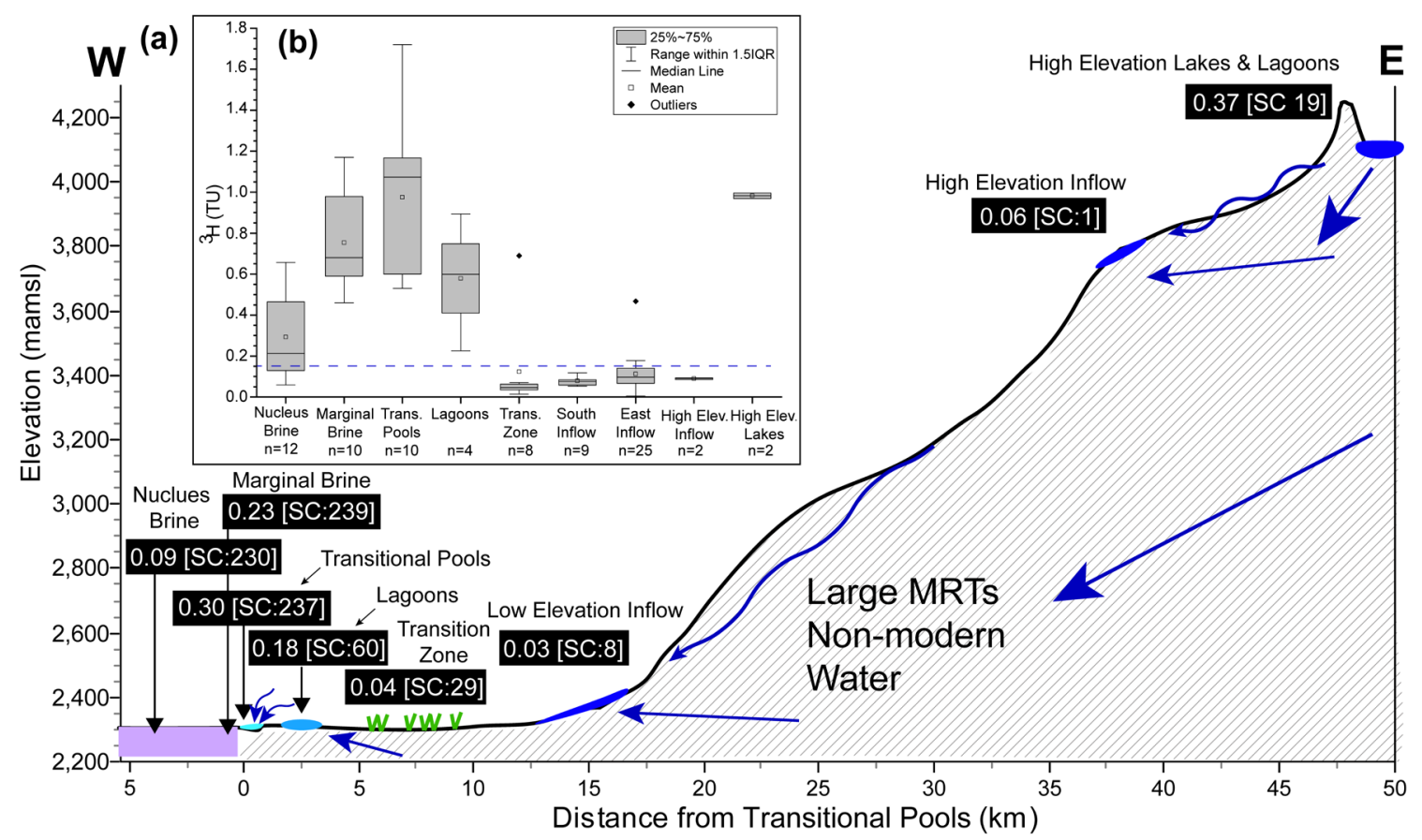

Figure 4. (a) Modern water proportion ( $R_{m o d}$ ) among groundwater and surface water bodies along a transect of the eastern Salar de Atacama margin. South Inflow and East Inflow waters are averaged as a single low elevation inflow water body. Mean $\mathrm{R}_{\bmod }$ value of each water grouping (in black rectangles) and mean Specific Conductivity (SC) in $\mathrm{mS} / \mathrm{cm}$. (b) Tukey box plot of ${ }^{3} \mathrm{H}$ content (TU) in these water bodies. Blue dashed line is the theoretical maximum limit (0.15TU) of background ${ }^{3} \mathrm{H}$ produced in-situ by waterrock interaction.

brackish Lagoons, shallow surface water bodies which occupy about $0.5 \mathrm{~km}^{2}$ and host important wildlife such as flamingos and brine shrimp. Transition Zone waters are shallow brackish groundwaters within the surficial gypsum dominated zone between the nucleus and the edge of the basin floor; South Inflow and East Inflow are fresh groundwater discharge waters entering the basin below 3000 mamsl; High Elevation Inflow waters are fresh groundwater discharge higher on the eastern slope of the basin; and the High Elevation Lakes are fresh-to-brackish lake waters just outside the watershed divide.

All ${ }^{3} \mathrm{H}$ data for each of these water bodies are summarized in Tukey Box plots and plotted along a transect through the eastern basin margin (Figure 4). Results show that waters discharging along the margin have values indistinguishable from zero as nearly all fall fully below the background threshold described above. The only two samples ( $73 \& 84)$ which have higher values and the few that are borderline above the background, in the Transition Zone and the East Inflow are in the proximity of preferential flow paths related to rapid infiltration of modern

311 precipitation into permeable alluvial fans, a process indicated by Boutt et al. (2016). The data

312 from high elevation lakes Miñiques and Miscanti (samples $11 \& 12$ ) as well as other surface 313 waters at high elevation (Laguna Lejía \& Pena Blanca) show much higher values, similar to the 


\begin{tabular}{|c|c|c|c|c|c|c|}
\hline Elevation of Lakes & & Hydraulic & & & & \\
\hline (mamsl): & 4150 & $\begin{array}{c}\text { Conductivity [K]: } \\
\text { Distance from }\end{array}$ & $K=15.5 \mathrm{~m} / \mathrm{d}$ & $K=5.0 \mathrm{~m} / \mathrm{d}$ & $\mathrm{K}=1.0 \mathrm{~m} / \mathrm{d}$ & $\mathrm{K}=0.01 \mathrm{~m} / \mathrm{d}$ \\
\hline Sample Site (name) & Elevation (mamsl) & Lakes (km) & $v(m / d)$ & $v(m / d)$ & $v(m / d)$ & $v(m / d)$ \\
\hline 13 (Socaire) & 3606 & 12 & 5.0 & 1.6 & 0.32 & 0.0032 \\
\hline 9 (Peine) & 2450 & 29 & 6.5 & 2.1 & 0.42 & 0.0042 \\
\hline 8 (Tilomonte) & 2373 & 33 & 6.0 & 1.9 & 0.38 & 0.0038 \\
\hline 84 (Truck) & 2329 & 34 & 5.9 & 1.9 & 0.38 & 0.0038 \\
\hline Sample Site (name) & \multicolumn{2}{|c|}{ Hydraulic Gradient [dh/dl] } & MRT (yrs) & MRT (yrs) & MRT (yrs) & MRT (yrs) \\
\hline 13 (Socaire) & \multicolumn{2}{|c|}{0.045} & 7 & 20 & 101 & 10146 \\
\hline 9 (Peine) & \multicolumn{2}{|c|}{0.059} & 12 & 38 & 190 & 18962 \\
\hline 8 (Tilomonte) & \multicolumn{2}{|c|}{0.054} & 15 & 47 & 235 & 23490 \\
\hline 84 (Truck) & \multicolumn{2}{|c|}{0.054} & 16 & 49 & 243 & 24333 \\
\hline \multirow[t]{2}{*}{ Sample Site (name) } & \multirow[t]{2}{*}{$\begin{array}{l}\text { Distance from } \\
\text { Lakes (km) }\end{array}$} & ${ }^{3} \mathrm{H}^{*}(\mathrm{TU})$ & $\begin{array}{l}\text { MRT w/Lake Water } \\
\text { Input (yrs) }\end{array}$ & $\begin{array}{c}\text { MRT w/Precipitation } \\
\text { Input (yrs) }\end{array}$ & \multicolumn{2}{|c|}{$v(m / d)$} \\
\hline & & 3.23 & - & - & $\begin{array}{c}\text { Assuming }{ }^{3} \mathrm{H}- \\
\text { Calculated MRT (w/ } \\
\text { lake water) }\end{array}$ & $\begin{array}{c}\text { Assuming }{ }^{3} \mathrm{H}- \\
\text { Calculated MRT (w/ } \\
\text { precip.) }\end{array}$ \\
\hline $11 \& 12$ (Miñ./Mis.) $\left[\mathrm{N}_{0}\right]$ & 0 & 0.67 & - & - & - & - \\
\hline 13 (Socaire) & 12 & 0.07 & 40 & 68 & 0.8 & 0.5 \\
\hline 9 (Peine) & 29 & 0.04 & 48 & 76 & 1.7 & 1.0 \\
\hline 8 (Tilomonte) & 33 & 0.08 & 37 & 65 & 2.5 & 1.4 \\
\hline 84 (Truck) & 34 & 0.32 & 13 & 41 & 7.2 & 2.3 \\
\hline
\end{tabular}

Table 1. Calculations of transit time estimates assuming piston flow and a decay constant. The High elevation lake water ${ }^{3} \mathrm{H}$ value and modern meteoric water are used as input ${ }^{3} \mathrm{H}$ values. These input values were decayed and seepage velocities (v) estimated with aquifer properties (K \& $\theta$ ) from Houston (2007) and a plausible range of values. Velocities were calculated by piston flow transit times, then the MRT of waters were estimated under these conditions.

314 average of Transitional Pool waters. Nucleus Brine waters are predominantly composed of pre315 modern groundwater with a small component of modern water in some samples, the Transition 316 Zone waters are entirely pre-modern while the Lagoons have a large component of pre-modern 317 water but some samples contain a substantial amount of modern water.

318 The spatial coverage and density of samples across the eastern margin, considering the 319 focused nature of groundwater discharge in the basin gives confidence that shallow inflow to the 320 salar is well-represented by this analysis and that nearly all of it is composed of pre-modern 321 water. It is also apparent that surface waters (Lagunas Miñiques, Miscanti, Lejía, and the 322 Transitional Pools) have an analogous signature of about $0.30-0.40 \mathrm{R}_{\text {mod }}$. This consistent 323 signature highlights and defines the substantial contrast between the surface water system and 324 groundwater system (surface water sample "Cerro Toco N" is the exception to this, likely 325 primarily composed of water sourced from the "Cerro Toco N" groundwater just upgradient)

326 (Figure 3). The interaction of these surface and groundwater systems serve to illuminate 327 hydrological mechanisms governing the system as a whole and constrain the distribution of 328 modern water within its sub-systems.

329 Since the groundwater can only be directly measured at discrete points and processes in 330 the thick vadose zone are not easily constrained, simple analytical representations with a range of 331 plausible hydrologic properties can facilitate interpretation of dominant processes controlling 
flow paths, MRTs and sources of groundwater inflow. Along a cross-section from the Transitional Pools to the High Elevation Lakes (Figure 4) we estimate the MRT of sampled groundwater discharge assuming a shallow flow path $(<100 \mathrm{~m})$, piston flow and a plausible range of hydraulic properties (Table 1). The MRT estimates for each groundwater discharge site were calculated independently using the observed ${ }^{3} \mathrm{H}$ values, a range of seepage velocities and measured hydraulic gradients $(\mathrm{dh} / \mathrm{dl})$ (Table 1$)$.

If we first assume the ${ }^{3} \mathrm{H}$ value of recharge water lies somewhere between modern precipitation and high elevation surface waters (as focused recharge from these waters bodies is thought to be important), it will decay according to this formula as it moves downgradient; where $\mathrm{t}=$ time, $\mathrm{N}=$ sample ${ }^{3} \mathrm{H}$ value, $\mathrm{N}_{\mathrm{o}}=$ initial ${ }^{3} \mathrm{H}$ value and $\lambda=$ the decay constant of ${ }^{3} \mathrm{H}$ :

$$
t=\frac{\operatorname{Ln}(N / N o)}{-\lambda}
$$

We then estimate how long it would take for that water to decay enough to match the ${ }^{3} \mathrm{H}$ value measured in groundwater discharging downgradient. This MRT is not intended to physically replicate the complexity of groundwater transport but paired with a range of seepage velocities, this places critical constraints on plausible MRTs. Using estimated effective porosity $(\theta)$ and a range of hydraulic conductivities (K) including values previously determined by Houston (2007) in a basin just north of Salar de Atacama, we calculated a seepage velocity for each sample site:

$$
v=(K / \theta) \times(d h / d l)
$$

We then determined the seepage velocity required for each flow path to reflect the MRT at each site estimated by simple ${ }^{3} \mathrm{H}$ decay. Lastly, we calculated the MRT for each sample using these estimated seepage velocities.

These results indicate that simple piston flow and ${ }^{3} \mathrm{H}$ decay predict a sizeable portion of young water not observed at these sites and would require seepage velocities much greater than would be reasonable in this environment. Two factors would suggest that actual MRTs of these waters resemble something closer to those predicted with the lowest velocities in Table $1 .{ }^{3} \mathrm{H}$ values in inflow waters are well below the background production envelope but are rarely zero, therefore the value used for those sites may be artificially high as some or all of the ${ }^{3} \mathrm{H}$ in these waters is potentially derived from in situ production or analytical uncertainty while its modern water content may, in fact, be approaching zero. The thick vadose zones in this environment may require hundreds of years or more for water to infiltrate (Herrera et al., 2016; Walvoord et al., 2002) leading to effective seepage velocities much smaller than reasonable hydraulic conductivity 
values in Table 1 would predict. Together this suggests that the low ${ }^{3} \mathrm{H}$ activities at these groundwater discharge sites cannot be explained by modern high elevation recharge flowing downgradient and becoming low elevation discharge within modern time frames; under the most plausible hydrogeologic conditions, it likely requires hundreds to thousands of years for high elevation recharge to reemerge as springs and diffuse groundwater discharge in the basin.

\subsection{Oxygen $\left({ }^{18} \mathrm{O} /{ }^{16} \mathrm{O}\right)$ and Hydrogen $\left({ }^{2} \mathrm{H} /{ }^{1} \mathrm{H}\right)$ Ratios in Water}

In this groundwater-dominated system, isotopic signatures of individual samples are primarily a reflection of its source water mixture and flow path characteristics. Comparing signatures in each discharge zone $(\mathrm{N}, \mathrm{NE}, \mathrm{SE}$, and $\mathrm{S})$ and recharge zone (North Divide, $\mathrm{NE}$ Divide, SE Divide, North Plateau, South Plateau-N and South Plateau-S) we can address important questions regarding dominant hydrological mechanisms governing the larger orogenicscale groundwater system. It is important to note that the western half of the basin is not included in our analysis of the Salar de Atacama system because actual inflow from that region is negligible when compared to the other zones, accounting for less than $1 \%$ of the total (Munk et al., 2018) (Figure 2). measured seasonally over a nearly 7-year period and more sporadically back to 1969 show

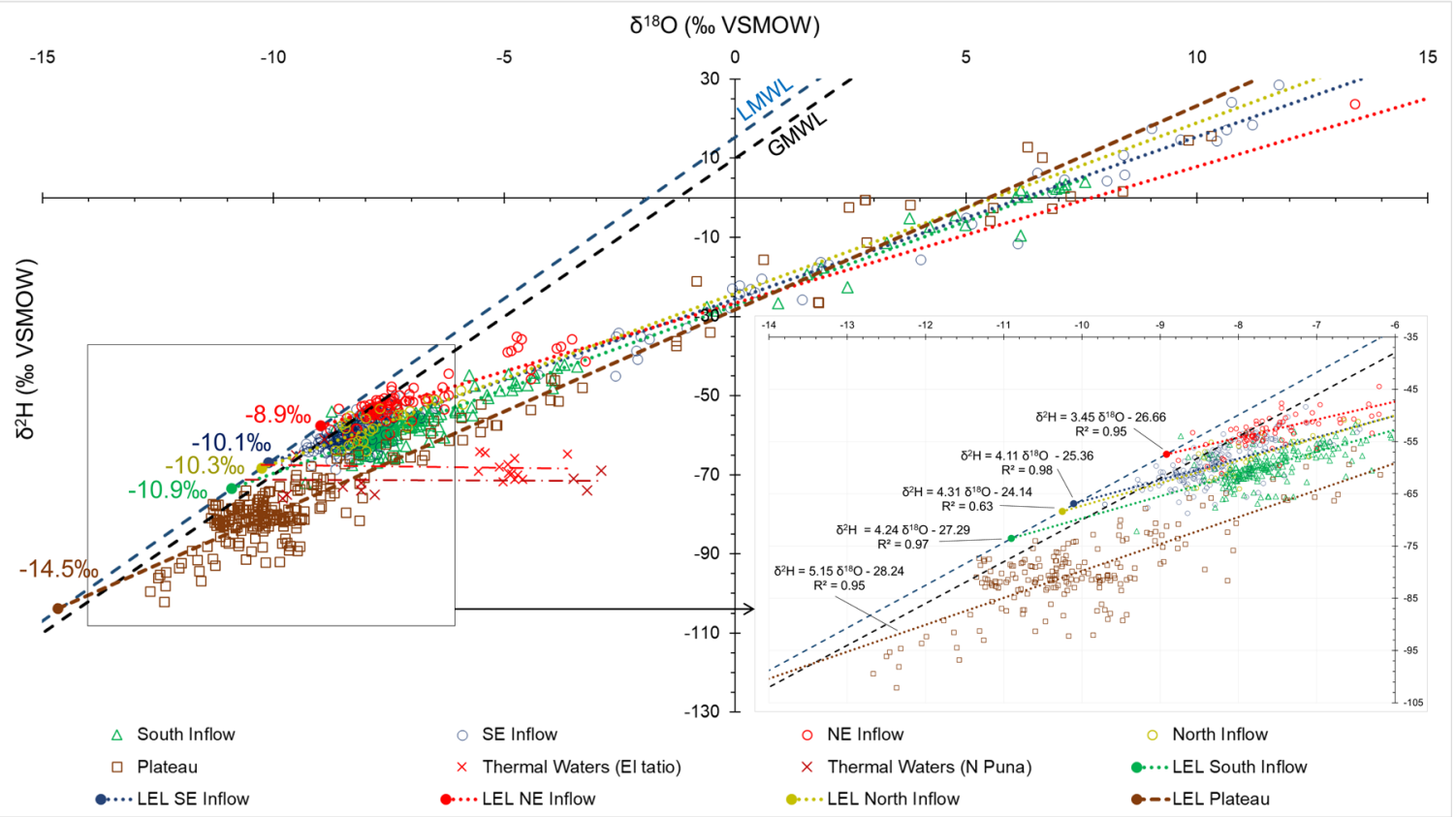

Figure 5. $\delta^{18} \mathrm{O}$ and $\delta^{2} \mathrm{H}$ of water from the Salar de Atacama regional watershed $(\mathrm{n}=889)$. Colors correspond to the three inflow zones labeled in Figure 2, brown points are all plateau waters. The meteoric source water isotopic signature is estimated for each zone where the LEL intersects the Local Meteoric Water line (LMWL) from Chaffaut et al. (1998). High-temperature waters from the El Tatio thermal field and northern Puna region indicated by red Xs. 
Manuscript submitted for Review in Water Resources Research - September 19, 2019

consistent values with some correlation to large local precipitation events but the responses are short-term (Figure S2). The documented major precipitation events in March 2012 and March 2015 appear to show negative deviations of 3-5\% in $\delta^{2} \mathrm{H}$, after which data revert to the long-term trend in a few months. This suggests a signature of local meteoric infiltration is observed at these sites below 3000 mamsl but is largely restricted to short time-scales, longer flow path waters are the principal control on isotopic values of inflow water. Data from the sample sites within the NE and SE zones have a mean standard deviation of 2.2\% and 2.8\% in $\delta^{2} \mathrm{H}$ respectively, reflecting variability between sites and the short-term influence of local recharge pulses. Stream gauge data at the Spring-fed streams also show influence from local recharge events but revert to a consistent long-term average value within a month or two (DGA, 2013). Since this analysis utilizes a large dataset collected over more than 20 years, we are confident that our analysis of environmental tracers reflects the long-term average discharge signal of the groundwater system.

All $\delta^{2} \mathrm{H}$ and $\delta^{18} \mathrm{O}$ data analyzed in this work are presented in Table S3, and are plotted in $\delta^{2} \mathrm{H}-\delta^{18} \mathrm{O}$ space along the GMWL and the modern Local Meteoric Water Line (LMWL) in Figure 5 (Chaffaut et al., 1998). To a first order it is apparent that a linear fit of all these data forms a line which is offset below but parallel to the LMWL; this phenomenon has been observed by several other workers in this basin and in other arid basins in the central Andes and worldwide (Aravena, 1995, 1999; Boschetti et al., 2007; Fritz et al., 1981; Koeniger et al., 2016; Margaritz et al., 1989). Also evident in these data is a bimodal distribution; one cluster has relatively depleted $\delta^{2} \mathrm{H}$, centered around $-80 \%$ and the other around $-60 \%$. Distinctions can also be identified between zones of inflow which indicate important spatial differences in discharge within the Salar de Atacama watershed.

The strong influence of kinetic fractionation due to evaporation in this region allows for back-calculation of the expected meteoric source waters for each of these zones (Text S4). By defining linear regressions of water data in each zone (Local Evaporation Lines (LEL)) we can predict the meteoric source $\delta^{18} \mathrm{O}$ and $\delta^{2} \mathrm{H}$ signature while also determining the slope characteristic of evaporative fractionation in each. Coefficients of determination $\left(\mathrm{R}^{2}\right)$ show these LEL describe the data well (0.95-0.98), except in the North zone (0.63) for which there is less confidence due to a relative lack of data $(n=24)$. The four inflow water zones are defined by slopes of $3.5(\mathrm{NE}), 4.1$ (SE), $4.2(\mathrm{~S})$ and $4.3(\mathrm{~N})$ while plateau waters show a steeper slope of 5.2 (Figure 5). These values are consistent with empirically derived LEL from this region and similar environments (Aravena, 1995, 1999; Boschetti et al., 2007, 2019; Ortiz et al., 2014; Scheihing et al., 2018). Shallower slopes reflect the higher average annual temperatures and lower relative humidity of 
413 the lower elevations, the steeper slope of high-altitude plateau waters reflects the higher average 414 relative humidity and lower temperatures there and associated smaller kinetic effects. Predicted 415 source waters derived by projecting these regressions to their intercepts with the LMWL show 416 that the meteoric source of the plateau water is substantially more depleted in $\delta^{18} \mathrm{O}$ and $\delta^{2} \mathrm{H}$ than 417 those of discharge waters within the basin. Inflow $\delta^{18} \mathrm{O}$ signatures are higher by about 5.6\%o 418 (NE), 4.4\%o (SE), 4.2\%o (N) and 3.6\% (S) than average plateau waters. We can, therefore, deduce 419 that substantial hydrogeological distinctions exist between these two systems.

421 spatially we compare isotopic signatures of the three recharge zones on the plateau and the three

422 recharge zones in the region straddling the divide. Again, plotted in $\delta^{2} \mathrm{H}-\delta^{18} \mathrm{O}$ space we compute

423 the predicted meteoric source of each recharge zone (Figure 6). These results show that waters of

424 the divide predict source waters comparable to those discharging directly downgradient in the 425 basin, implying that the predominant source signature of these waters is largely analogous. In 426 comparison, the three zones on the plateau show substantially lower $\delta^{18} \mathrm{O}$ and $\delta^{2} \mathrm{H}$ signatures 427 suggesting these waters have a different meteoric source from both the inflow waters and the 428 divide waters. The zone covering the largest area of any (North Plateau) appears to be the most 429 distinct from the Salar de Atacama watershed inflow with $\delta^{18} \mathrm{O}$ values between $5.2 \%$ and $7.2 \%$ 430 lower. Further statistical scrutiny of these data provides a better definition of these distinctions.

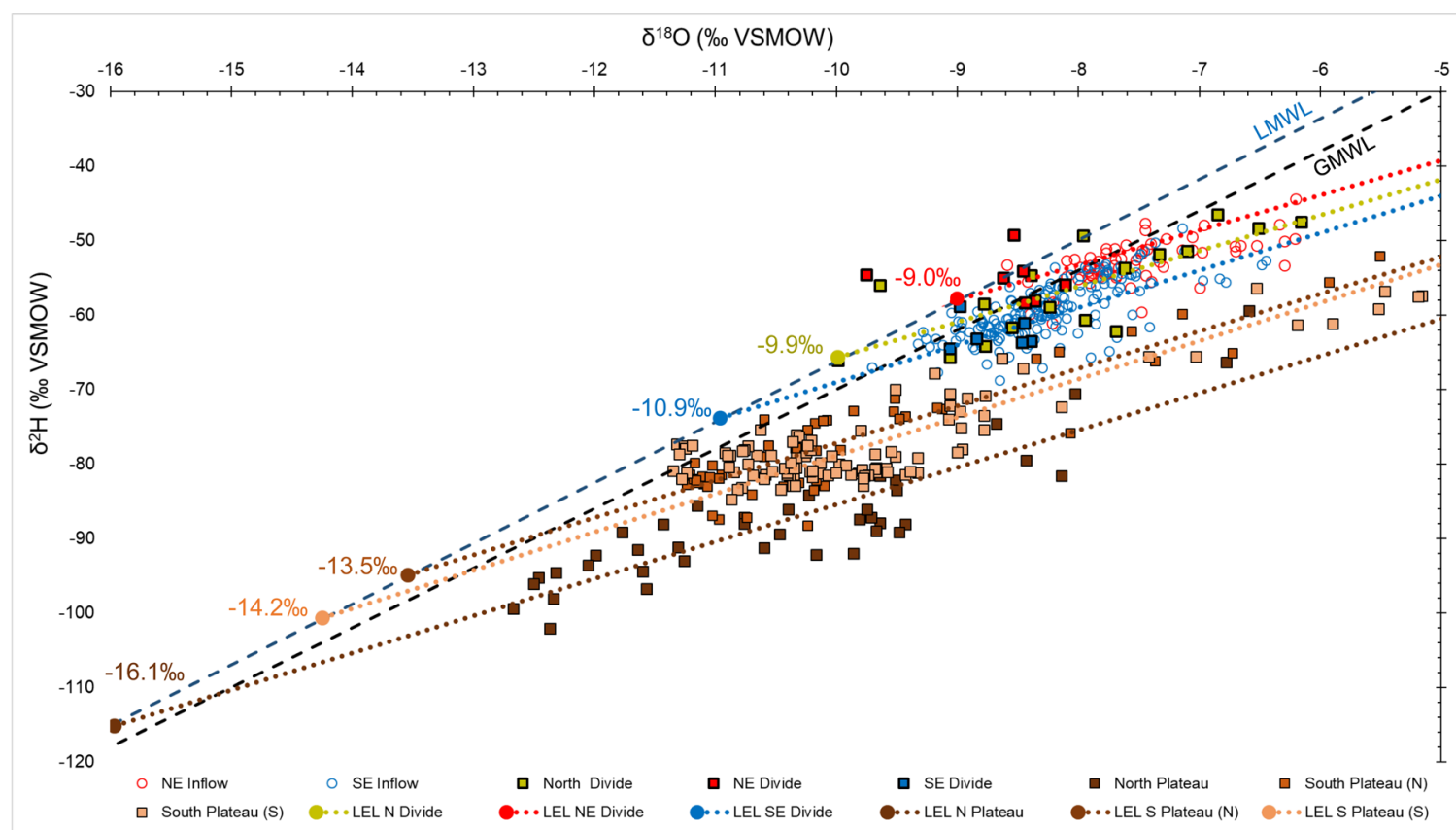

Figure 6. $\delta^{18} \mathrm{O}$ and $\delta^{2} \mathrm{H}$ of water from the plateau and divide recharge zones. Inflow waters (NE and SE zones) are red and blue points displayed for context. Predicted meteoric source waters from LEL intercept with LMWL are colored numbers. 
Manuscript submitted for Review in Water Resources Research - September 19, 2019

$\delta^{18} \mathrm{O}$ data from all zones were filtered with the deuterium-excess (d-excess) parameter and summarized statistically (Figure S3). Separating samples with a d-excess less than zero is

433 considered the optimal point for removing most kinetic influences while maintaining the

434 maximum number of samples uninfluenced by evaporative effects (Jasechko et al., 2014).

435 Removing the kinetic evaporative influence from our dataset allows for direct comparison

436 between inflow waters by including only those most representative of their original meteoric

437 source. This analysis provides further evidence of the large statistical distinctions between all

438 Salar de Atacama inflow water and waters on the plateau, also that there is less apparent

439 distinction between the inflow and the divide waters. We find the mean $\delta^{18} \mathrm{O}$ value of $\mathrm{NE}$ inflow

440 zone water is about $1.3 \%$ higher than the divide waters upgradient, the SE inflow water values

441 are about $0.4 \%$ higher than its corresponding divide waters and the $\mathrm{N}$ zone waters appear

442 analogous to its corresponding divide waters. There is also a clear statistical distinction between

443 the NE and SE inflow waters, one which is exhibited by the calculated meteoric source showing

444 the mean $\delta^{18} \mathrm{O}$ value of $\mathrm{NE}$ waters is about $1 \%$ higher than the mean SE waters. This suggests

445 meaningful differences between sources and/or groundwater mechanisms governing the NE and

446 SE inflow.
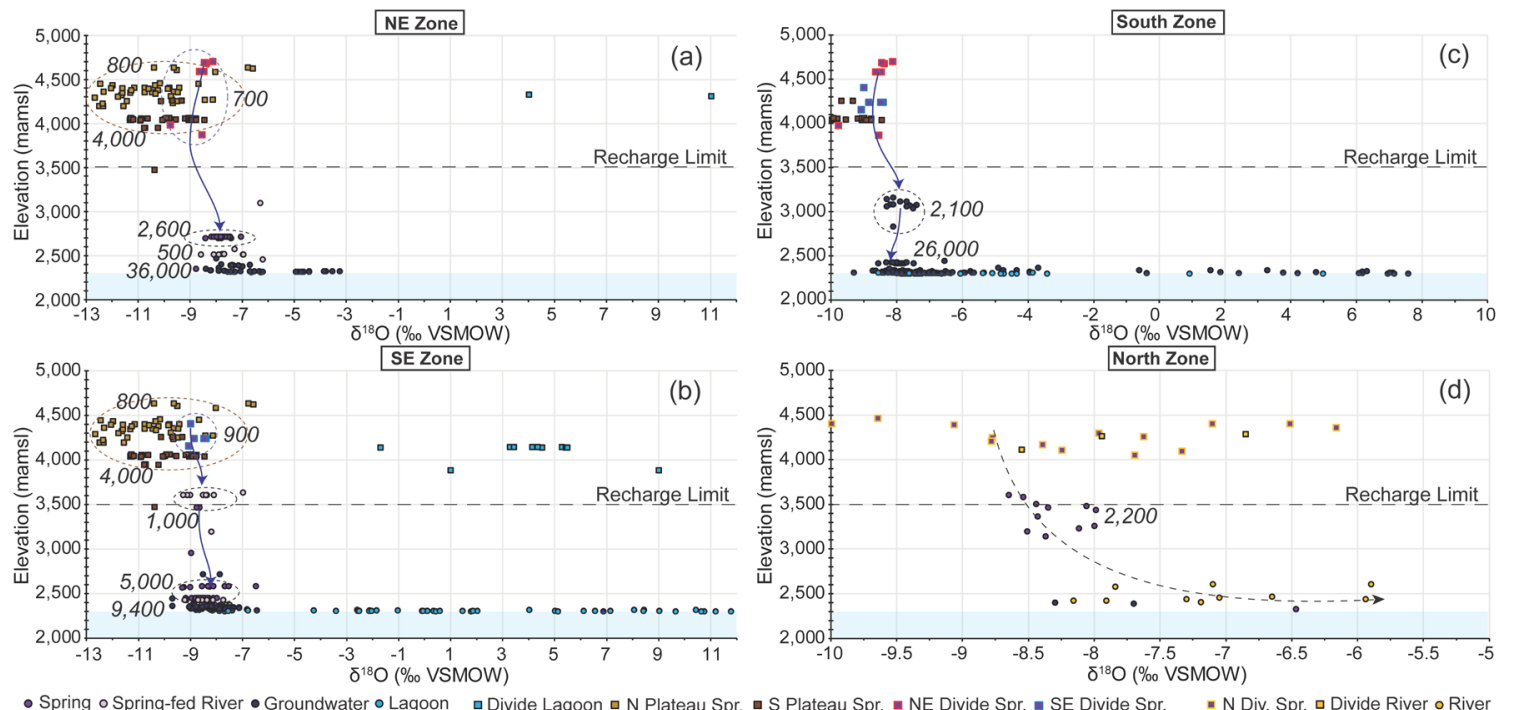

Figure 7. $\delta^{18} \mathrm{O}$ in waters from each zone plotted against sample elevation. Recharge limit line denotes elevation below which no significant recharge occurs; Houston (2009), Scheihing et al. (2018) and others have shown for this region the limit lies at $\sim 120 \mathrm{~mm}$ of precipitation per year (Figure 1). Blue shaded envelope represents the salar evaporite aquifer below the basin floor. Specific Conductivity $(\mu \mathrm{S} / \mathrm{cm})$ of sample groupings in italics. Ellipses in (a), (b) and (c) indicate descriptive groupings discussed in text and blue arrows indicate general hydrochemical evolutionary pathways. Dashed arc in (d) indicates the predicted trend of isotopic evolution in a river system. Water types and locations are labeled in legend (Spr.=Spring water). 
Manuscript submitted for Review in Water Resources Research - September 19, 2019

These same d-excess filtered data from each compartment were compared using an unequal variances t-test (Welch's test) to assess the null hypothesis that samples within each zone represent waters from the same population. $\delta^{2} \mathrm{H}$ and $\delta^{18} \mathrm{O}$ values of these water groupings were compared: All Divide - All inflow (N, NE, SE, S); All Plateau - All Inflow; All Divide - All Plateau; NE - SE and SE - S. Results show strong statistical difference $(\mathrm{P}<0.0001)$ between all these zones except for All Divide - All inflow $(\mathrm{P}=0.035)$ for both $\delta^{2} \mathrm{H}$ and $\delta^{18} \mathrm{O}$ and $\mathrm{SE}-\mathrm{S}$ $(\mathrm{P}=0.164)$ for $\delta^{2} \mathrm{H}$ values only. Divide waters and inflow waters are not statistically distinct in terms of $\delta^{2} \mathrm{H}$ or $\delta^{18} \mathrm{O}, \mathrm{S}$ and SE waters are distinct with respect to $\delta^{18} \mathrm{O}$ but not distinct with respect to $\delta^{2} \mathrm{H}$, which indicates another hydrological process may be influencing waters in the South zone.

To compare groundwater flow paths into the basin, we trace the isotopic evolution of waters moving through each inflow zone. Figure 7 shows $\delta^{18} \mathrm{O}$ by sample elevation for each inflow zone and the recharge waters upgradient of them. Waters in each zone show a general trend of increasing salinity with decreasing elevation toward the Salar de Atacama basin aquifer. This trend is expected as more dissolved solids can be accumulated in groundwater from rock weathering and re-mobilization of residual salts present in the aquifer material. While a substantial increase in salinity downgradient indicates waters are evolving geochemically, $\delta^{18} \mathrm{O}$ values only increase by about $0 \%$ - $2 \%$ o between divide recharge and discharge waters. This has been observed in previous work in this region showing increasing salinity with no isotopic evolution reflects "salinization" of fresh groundwater inflows, not evaporative enrichment (Fritz et al., 1978; Risacher et al., 2003). The evolution observed in the NE, SE and S waters show that groundwaters discharging near the salar margin have a direct relationship to that of groundwaters in the divide recharge area upgradient but not the majority of the plateau waters. The overlap that occurs between some plateau waters and divide waters, especially in the SE suggests there is at least some connection between portions of the plateau and Salar de Atacama inflow. The south zone displays similar characteristics to the $\mathrm{NE}$ and SE but also a slight decrease in $\delta^{18} \mathrm{O}$ values from the groundwater in the central MNT aquifer to discharge near the Tilopozo wetland. In the $\mathrm{N}$ zone where two large perennial rivers flow to the basin floor, waters follow a trend more typical of a surface watershed where the lower reaches are steadily isotopically evolved due to strong evaporative fractionation. ${ }^{87} \mathrm{Sr} /{ }^{86} \mathrm{Sr}$ data presented by Munk et al. (2018) indicate that some of the sub-basins (e.g. Miscanti) on the divide and plateau have direct geochemical connections to downgradient inflow areas, while others appear quite disconnected. Since actual recharge is insignificant where annual precipitation is less than $120 \mathrm{~mm} /$ year (equating to an 
Manuscript submitted for Review in Water Resources Research - September 19, 2019

elevation of $\sim 3500$ mamsl), these results suggest the predominant source of inflow is upgradient groundwaters, not local inputs (Houston, 2009; Houston, 2007; Houston \& Hart 2004).

\subsection{Constraining Modern Meteoric Inputs}

Air mass tracking of major precipitation events reveal macro-scale features of the modern climate regime and allow for comparison between meteoric recharge inputs to the plateau and ultimately the inflow zones (Figure S4). Our results indicate that nearly all precipitation is derived from either the northeast or east and any distinctions in meteoric input signatures to this system are more a consequence of localized convectional and orographic effects than distinctions between initial moisture source. Prominent orographic barriers exist along the length of the watershed divide and along an NW to SE trending chain of volcanoes to the east of Laguna Miñiques which may develop distinctive average meteoric input signatures among recharge zones and inflow waters to the Salar de Atacama basin.

\section{Discussion}

Our integrated analysis of isotope systematics in the waters of Salar de Atacama regional watershed defines the spatiotemporal dimensions of dominant sources and flow paths, the distribution and degree of connection among water bodies, sub-catchments and perched basins on the Altiplano-Puna plateau, and distinctions between the modern and paleo-hydrological systems. We show that inflow to the basin is not predominantly composed of recharge on the plateau, modern recharge ( $<60$ years old) on the high elevation watershed divide or local, modern inputs within the watershed. We conclude this based on the following lines of evidence: (i) there are substantial distinctions between the $\delta^{18} \mathrm{O}$ and $\delta^{2} \mathrm{H}$ signatures of Salar de Atacama inflow water versus waters on the plateau; (ii) nearly all waters discharging in the basin are composed of premodern water, and modern water that exists is limited and focused in nature, and (iii) based on the physical properties of this system, modern groundwater recharge within the watershed and on the divide would likely take hundreds of years or more to become groundwater discharge in the basin. Therefore, the draining of transient storage in the groundwater system over large time scales must be a critical component of the present water budget. We also propose that the influx of solute-rich underflow from high elevation basins over long time-scales, predominantly in the southern and eastern regions is an important mechanism to account for the large solute (Na and Cl) imbalances in hydrological budgets (Munk et al., 2018). These governing mechanisms are defined in a fully integrated conceptual model of this system as it currently exists, placing critical constraints on fundamental hydrological processes controlling orogenic-scale groundwater 


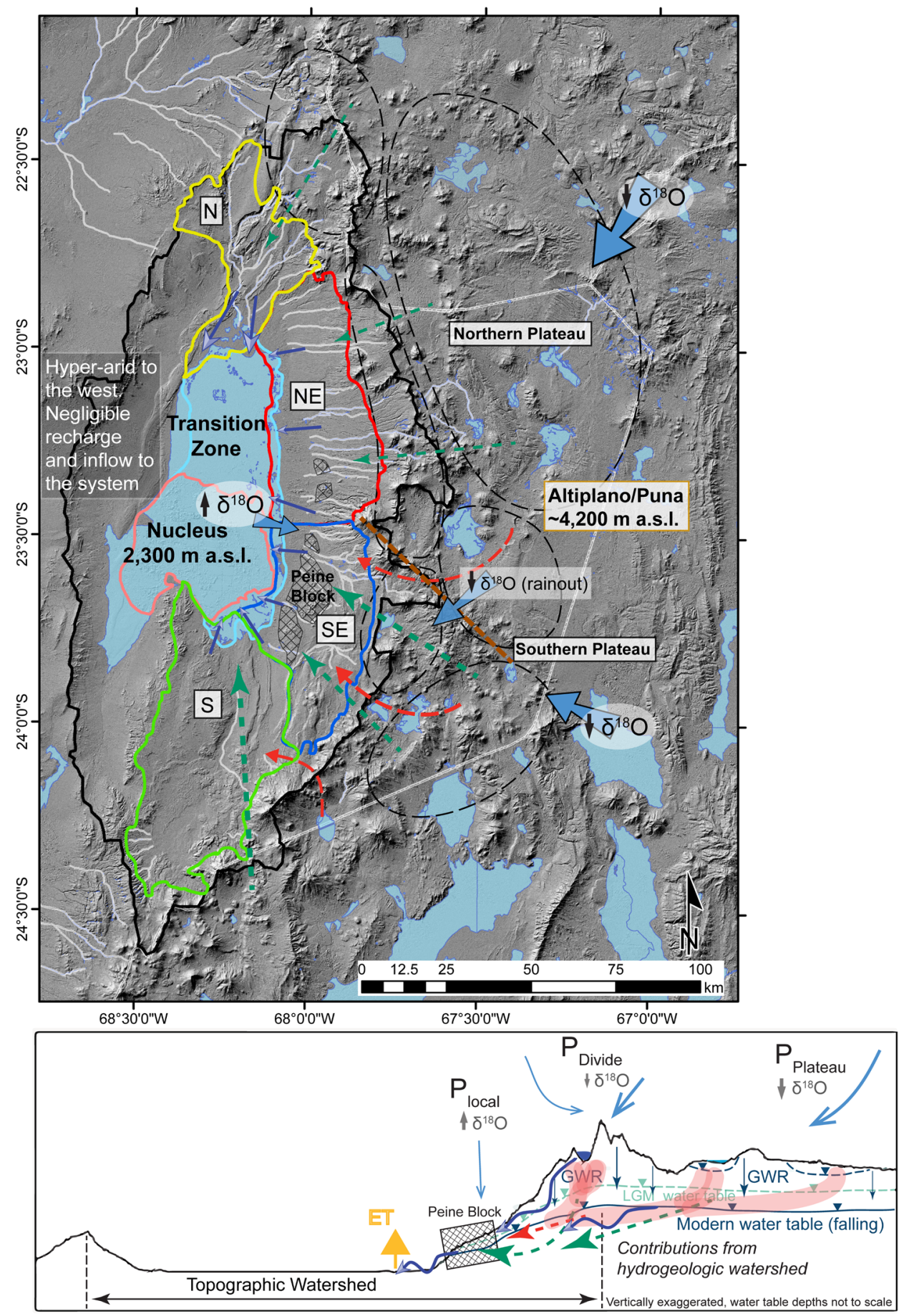

Figure 8. Conceptual model of the Salar de Atacama regional groundwater system, major mechanisms governing the contemporary hydrologic system and their relative influence (adapted from Corenthal et al. 2016). In plan view (a), solid light blue arrows represent the distribution of modern meteoric inputs and their signatures, the brown dashed line denotes a major orographic barrier to precipitation east of Miñiques and Miscanti lakes. Solid blue arrows represent inflows of modern recharge, green dashed arrows are major inputs of paleo-groundwater, red dashed arrows show hypothesized influx of solute-rich fluid. (b) Cross-sectional view of the SE zone shows the distribution and relative importance of these hydrological mechanisms. Blue lines are estimated position of the modern water table, green is the LGM water table and the corresponding flow paths of modern and fossil groundwater, red is solute-rich influx. 
Manuscript submitted for Review in Water Resources Research - September 19, 2019

systems (Figure 8). Our results reveal novel insights about these large-scale systems and provide a framework within which to address important unresolved questions in these basins

515 worldwide.

516 Analysis of ${ }^{3} \mathrm{H}$, the long-term stability of isotopic signatures in groundwater discharge

517 and insignificant direct recharge occurring at low elevations indicate that inflows from the

518 southern and eastern margins of Salar de Atacama are principally composed of pre-modern

519 recharge. These inflow waters which represent a large portion of total water flux $(\sim 65 \%)$ and

520 solute flux into the basin are, principally, expressions of a regional hydrologic system decoupled

521 from modern inputs (Munk et al., 2018). Surface waters bodies at high and low elevations

522 (Laguna Miñiques, Miscanti, Lejía, and the Transitional Pools) have a consistent signature of

523 about $30 \%$ modern, reflecting a dynamic equilibrium between ${ }^{3} \mathrm{H}$-rich modern recharge, ${ }^{3} \mathrm{H}$-dead

524 groundwater inflows, and discharge fluxes. This consistent signature among these waters which

525 have direct connections to modern meteoric inputs highlights a clear contrast between surface

526 water systems and the groundwater system. The prevalence of pre-modern water observed in

527 inflow to the basin, the timing of past pluvial periods ( $>1000 \mathrm{yrs}$.), thick vadose zones (up to

$5281000 \mathrm{~m}$ or more) and the large scales over which these flow paths must develop reveal a

529 groundwater system which operates over time scales of 100-10000 years or longer. Taken

530 together, these results indicate that the Salar de Atacama hydrologic system is fundamentally

531 groundwater controlled and strongly compartmentalized by source and flow path over small

532 spatial and vertical distances.

533 Large infrequent precipitation events observed and described by Boutt et al. (2016) and

534 others which do infiltrate and move along preferential flow paths near the margin of the evaporite

535 deposit are governed by the presence of alluvial fans with high infiltration capacities and by sharp

536 saltwater-freshwater interfaces created by the dense brine of the evaporite aquifer. These

537 interfaces which exist near the surface in the transition zone are remarkably stationary and restrict

538 infiltration of fresher water, creating pathways of preferential flow on the margins of the salar

539 (McKnight, 2019). This modern meteoric water is directly reflected in the elevated ${ }^{3} \mathrm{H}$ values

540 observed in the Transitional Pools near the margin of the salar nucleus, in some areas of the

541 lagoons and in isolated shallow groundwater in some alluvial fans. The lagoons respond to this

542 focused infiltration and flow by occasionally flooding during extreme precipitation events near

543 the basin floor but largely return to their original shape and volume within months. This is

544 supported by the findings of Boutt et al. (2016) showing responses in the shallow brine aquifers

545 to large precipitation events on the salar are muted and short-lived and that the groundwater- 
dominated lagoons show little permanent response to these events. Lagoon water ${ }^{3} \mathrm{H}$ compositions show they are predominantly composed of pre-modern groundwater inflow and that floodwater likely exists as a lens above the much denser lagoon water, focused and channelized by the low permeability gypsum covering much of the transition zone. The few Transitional Pool waters which were sampled just below the salar surface south of the open pools also contain substantial amounts of this modern water as well as the lagoon sample "La. Brava B", taken from a shallow arm of the lagoon in the path of one of these focused flow paths. The waters along the transition zone-nucleus margin are controlled by exchanges between these modern meteoric water lenses and pre-modern groundwater inflow from below. The ${ }^{3} \mathrm{H}$ content of lagoon waters and waters in the transition zone subsurface likely reflect the mixing of small volumes of this modern water with much larger volumes of pre-modern inflow. Though the specific dynamics of these lenses and their interaction with groundwater requires further inquiry, there is ample evidence that modern water effectively bypasses the lagoons themselves in these lenses and migrates toward the Transitional Pools where it dissolves and infiltrates through the porous halite units at the nucleus margin.

Recent research of global climate change indicates that in this region of the Andes and Preandean depression an increase in overall moisture and also large precipitation events is predicted due to a southward shift in the South American Monsoon (Jordan et al., 2019; Langenbrunner et al., 2019; Pascale et al., 2019). The substantial increase in extreme precipitation events observed since 2012, with one 4-day event in February 2019 recording $~ 100 \mathrm{~mm}$ of rain on the salar surface which normally receives only $15 \mathrm{~mm} /$ year (personal communication with Albemarle corp., July 2019) may, in fact, be a direct result of these large-scale climate changes and are likely to continue. The recent observations of persistent surface water expansion in the transition zone of Salar de Atacama (particularly the Transitional Pools) may also be a result of these decadal-scale changes in meteoric inputs, not a direct result of extractions from the brine aquifer or long-term changes associated with fluctuations in paleo-groundwater inflow.

Region-wide analysis of stable $\mathrm{O}$ and $\mathrm{H}$ isotope systematics reveal that each water inflow zone is defined by a distinct combination of sources and flow paths relating directly to their geology, meteoric inputs and connections to high elevation sub-basins beyond the watershed divide. Our analysis shows important variations in spatiotemporal connectivity between these high elevation zones and inflow to the basin which illustrates a heterogeneous and compartmentalized regional flow regime. The results of HYSPLIT back trajectories and our understanding of the modern climate regime show that differences in atmospheric source to 
Manuscript submitted for Review in Water Resources Research - September 19, 2019

recharge and discharge zones are not significant and cannot explain the substantial differences in isotopic signature we observe between inflow and recharge. Ultimately, meteoric water in the system is derived almost entirely from the Amazon and Chaco basins to the east, as this moisture traverses the Andean plateau it undergoes substantial rainout and recycling fractionation. The average isotopic signature of meteoric waters in each zone and their associated groundwaters reflect the orientation of their respective recharge areas in relation to the dominant moisture sources and the topographic barriers they interact with. Specifically, the $1-1.2 \%$ higher $\delta^{18} \mathrm{O}$ values observed in waters discharging from the NE zone relative to the SE zone is due to the lack of rainout fractionation in precipitation reaching its major recharge areas and the fact that the NE Divide zone is $\sim 250 \mathrm{~m}$ lower in average elevation than the SE Divide. With estimated $\delta^{18} \mathrm{O}$ lapse rates between $-0.9 \%$ and $-1.7 \%$ per $\mathrm{km}$ of elevation (Rohrmann et al., 2014), the difference in recharge elevation could account for only about $0.2-0.4 \%$ of this difference. The prominent topographic barrier that exists to the east of the Miñiques and Miscanti lakes (controlled by the COT fault system) may lead to consistent further isotopic depletion of precipitation in the SE zone contributing areas (Pingel et al., 2019) (Figure 8). This is also reflected in the nearly 2.0\%o higher $\delta^{18} \mathrm{O}$ values observed in the NE Divide waters relative to SE Divide waters.

The influence of snowmelt on groundwater recharge has been discussed as an important control on the isotopic signature of groundwater in this region (Herrera et al., 2016). We argue that since there are no permanent or deep seasonal snowfields in the entire region, snowfall is distributed quite uniformly across the high altitudes and likely $20-30 \%$ of the snow is sublimated before infiltrating, the signal of this snowmelt would not lead to systematic differences between recharge zones or inflow zones not already discussed herein (Beria et al., 2018; Stigter et al., 2018; Vuille \& Ammann, 1997). In addition, the dominant moisture source and general climate regime is not believed to have changed substantially through multiple pluvial periods during and since the last glacial maximum (LGM), it was simply more amplified (Godfrey et al., 2003). This suggests that the background precipitation isotopic signatures in each of these zones due to orographic effects and moisture source likely has not varied substantially through multiple pluvial periods. However, it would be expected that the isotopic signature of this pluvial recharge would have a distinct signature which can be identified.

Oxygen and hydrogen isotope ratios in water data presented here consistently align parallel to but below the LMWL and GMWL in $\delta^{18} \mathrm{O}-\delta^{2} \mathrm{H}$ space, indicating another important and consistent distinction between modern meteoric water and groundwater. A similar signal has been identified in the Central Andes and in other arid regions for which two explanations have 
612 been proposed: the continued evaporation of water during infiltration through the unsaturated

613 zone (Barnes \& Walker, 1989; Fontes \& Molinari, 1975; Zimmerman et al., 1967) and a direct

614 signature of pluvial groundwater recharge (Fritz et al., 1981; Magaritz et al., 1989; Meijer \&

615 Kwicklis, 2000). Laboratory and field measurements of diffuse recharge in arid environments

616 estimate that d-excess excursions in groundwater recharge can range between $0 \%$ to as much as -

617 10\%o relative to the initial meteoric water (Barnes \& Allison, 1988; DePaolo et al., 2004). In this

618 region it is likely that the actual influence of this process is less than the maximum due to the fact

619 that much of the recharge occurring here is focused (i.e. through fractures and at permeability

620 contrasts) not diffuse, is heavily biased to larger precipitation events and occurs at the highest

621 elevations where there are steeper LEL slopes than in most arid environments. Recharge waters

622 from wetter periods in the past would fall along a different GMWL than the modern due to

623 differences in composition of the global ocean and the substantially higher relative humidity in

624 this region would shift the LMWL (Meijer \& Kwicklis, 2000). This paleo-meteoric water line

625 during the most recent pluvial periods, for instance, is predicted to have a y-intercept of between

6260 and 5, resulting in a d-excess excursion from the modern LMWL of between -10\%o and -15\%o

627 (Clark \& Fritz, 1997; Fritz et al. 1981). The observed excursion (1c-excess) in the SE and NE

628 zone groundwaters and spring waters show an average of $-10 \%$, the South zone $-19 \%$ and high

629 elevation waters -16\% (Landwehr \& Coplen, 2006). While both of these processes likely have

630 some influence on these observed isotopic shifts, the magnitude of the shift we document

631 suggests that only a portion of this signal can be accounted for with vadose zone fractionation.

632 We argue that this signature has a fingerprint of pluvial period groundwater recharge now

633 draining from storage. A similar signature has been identified in groundwater isotope data in arid

634 regions worldwide where large water and solute imbalances have also been observed, this may

635 indicate the relative influence of draining paleo-recharge and help explain these imbalances.

$636 \quad \delta^{18} \mathrm{O}$ and $\delta^{2} \mathrm{H}$ data from the South zone and the plateau zones appear to be skewed further

637 off the LMWL (illustrated by their large lc-excess) giving these waters an apparent LEL slope

638 shallower than would be expected (Figure 5). Additional fractionation caused by isotopic

639 exchange from interactions between silica-rich rock and high-temperature fluids has been

640 documented in this and other regions with high tectonic activity, tending to evolve waters along a

641 nearly horizontal slope in $\delta^{2} \mathrm{H}-\delta^{18} \mathrm{O}$ space (Cortecci et al., 2005; Rissmann et al., 2015).

642 Thermal waters from two sites in the El Tatio geothermal field, northern Chile (Cortecci et al.,

643 2005) and Jujuy Provence on the northern Puna plateau of Argentina (Peralta Arnold et al., 2016)

644 provide approximate end-members with which to identify this influence (Figure 5). This shift

645 superimposed on the data is apparent in the plateau and South zone waters by the considerable 
Manuscript submitted for Review in Water Resources Research - September 19, 2019

skew off the LMWL towards this geothermal end-member. This process may help explain some of the apparent isotopic distinctions seen in the South zone waters with respect to the other inflow zones. Waters discharging in the South may, in fact, be more similar to the SE waters in source but are further fractionated as they flow towards the basin by remnant heat from the Socompa volcano, as indicted by Rissmann et al. (2015).

This work describes a large-scale integrated groundwater system where water is transported over long time-scales and across a vast regional catchment, therefore it is also likely that groundwater discharging to the Salar de Atacama basin is connected to some degree with the many internally drained sub-basins at high elevation (Figure 8). This solute-rich interbasin flow has been suggested by Grosjean et al. (1995), Munk et al. (2018) and Rissmann et al. (2015) among others as an important source of solutes to the Salar and explains in large part, the excess mass accumulated in the evaporite deposit. Three pieces of evidence in our results support this interpretation: (i) the regions we call the Divide zones, straddling the Salar de Atacama watershed divide have water isotope signatures that are consistent with groundwater discharge in the basin and therefore also consistent with infiltration occurring within these perched watersheds; (ii) the density of active salars and salt lakes close to the watershed divide, bounded to the north by the COT fault system is much higher than in the northern half of the basin; and (iii) the waters in the South and SE zone have much higher concentrations of conservative solutes than other parts of the basin as discussed by Munk et al. (2018).

\section{Conclusions}

Our exhaustive examination of isotopic systematics in this orogenic-scale groundwater system defines a regionally integrated system in which transient draining of groundwater from storage over long time scales is a fundamental control. This fossil water still moving through the system reflects catchment-wide dynamic responses to multiple large-amplitude climatic fluctuations over $10^{2}-10^{4}$ year time scales and represents a critical portion of the present water budget of the Salar de Atacama basin. We show that modern water in the system is limited, predominantly confined to shallow preferential flow paths near the margin of the salt flat and in alluvial fans. The movement of modern water and fossil water in the system is highly compartmentalized over small spatial and vertical distances. In addition, we show that groundwater recharge on much of the Altiplano-Puna plateau ( $>100 \mathrm{~km}$ from the salar) is decoupled from groundwater currently entering the basin but that the high elevation area straddling the watershed divide and the sub-basins just beyond constitute the primary recharge area to the basin. This work offers compelling evidence that evaluations of water use and 
sustainability in this region must integrate modern observations with an understanding of processes operating across large spatial and temporal scales. As an archetype of arid continental basins worldwide, these mechanisms, to varying degrees are critical for reconciling observed imbalances and must be spatiotemporally constrained in any model representing these systems. This work provides a framework within which to identify these mechanisms and connections at the catchment scale thereby allowing water resources to be more responsibly developed worldwide.

While this work significantly advances our understanding of the spatiotemporal dynamics controlling these large groundwater systems, outstanding questions relating to catchment-wide response times to changes in recharge and water tables remain. Specifically, how connected are high elevation recharge areas and sub-basins near the divide to groundwater discharge in the Salar de Atacama basin, what are the response times to these changes and how do they vary across the system. To address these questions, we propose a few main lines of further inquiry: i) filling in gaps in the transit time distribution of groundwaters throughout the system to further discretize fossil waters $>1000$ years old; ii) detailed hydrogeochemical analysis of flow paths and geochemical evolution in waters entering the basin and in the recharge areas to delineate flow regimes in the groundwater system at much finer resolution and with depth; iii) paleo-hydrologic reconstruction of conditions at the high elevation basins, groundwater discharge sites along the margin of Salar de Atacama and within the evaporite depocenter; and iv) fully integrated hydrogeological modeling to physically resolve the nature and time scales over which these systemwide connections exist.

\section{Acknowledgments}

The authors want to thank Scott Hynek for the extensive advice and consultation he provided on this work, it greatly improved the clarity of this manuscript; and Linda Godfrey for providing valuable unpublished data to supplement our dataset. We would also like to acknowledge Albemarle Corp. for their continued support of this and related research to improve the fundamental understanding of the hydrogeology and geochemistry of the Salar de Atacama environment. We are grateful for their permission to publish geochemical data relevant to this manuscript. The ASTER DEM and Landsat 8 OLI were retrieved from EarthExplorer, courtesy of the NASA Land Processes Distributed Active Archive Center, USGS/Earth Resources Observation and Science Center. The data used in this work is available on the WaterIsotopes Database (http://wateriso.utah.edu/waterisotopes/pages/spatial db.html). 
Manuscript submitted for Review in Water Resources Research - September 19, 2019

711 Figure Captions:

712 Figure 1. Digital elevation map of the Central Andes. Salars, lagoons and major drainages

713 (quebradas and rivers) are light blue. Topographic watersheds of major basins are outlined in

714 black. Extent of the Preandean Depression and Altiplano-Puna plateau are outlined in white

715 dashes. Isohyetal contours in $\mathrm{mm} /$ year are dark blue dashed lines. Locations of generalized

716 geologic cross-sections in Figure S1 are red. Red dots are precipitation gauges and sites used for

717 HYSPLIT models. MNT Trough structure is shaded.

718 Figure 2. The Salar de Atacama topographic watershed (solid black line), its recharge zones

719 (black dashed ellipses) and discharge/inflow zones (solid colored lines). Dots represent sample

720 sites, grouped by water type. Discharge zones extend from the salar margin to 4000 mamsl.

721 Major drainages (quebradas and rivers) are shown in white and salars and lagoons in light blue

722 and dark blue respectively. Notable high elevation lagoons Miñiques, Miscanti and Lejía are

723 labeled. Surface expression of the Peine/Cas structure is hatched.

724 Figure 3. Modern water content in samples $(n=87)$ proportional to circle size. Shaded areas are

725 inflow water zones. Data from Grosjean et al. (1995) are orange. Circles in Nucleus and

726 Transition Zone represent averages of water bodies. Surface waters (sw) are outlined in red,

727 groundwaters (gw) in blue.

728 Figure 4. (a) Modern water proportion (Rmod) among groundwater and surface water bodies

729

730

731

732

733 along a transect of the eastern Salar de Atacama margin. South Inflow and East Inflow waters are averaged as a single low elevation inflow water body. Mean Rmod value of each water grouping (in black rectangles) and mean Specific Conductivity (SC) in $\mathrm{mS} / \mathrm{cm}$. (b) Tukey box plot of $3 \mathrm{H}$ content (TU) in these water bodies. Blue dashed line is the theoretical maximum limit ( $0.15 \mathrm{TU})$ of background $3 \mathrm{H}$ produced in-situ by water-rock interaction.

Figure 5. $\delta^{18} \mathrm{O}$ and $\delta^{2} \mathrm{H}$ of water from the Salar de Atacama regional watershed $(n=889)$. Colors correspond to the three inflow zones labeled in Figure 2, brown points are all plateau waters. The meteoric source water isotopic signature is estimated for each zone where the LEL intersects the Local Meteoric Water line (LMWL) from Chaffaut et al. (1998). High-temperature waters from the El Tatio thermal field and northern Puna region indicated by red Xs.

739 Figure 6. $\delta^{18} \mathrm{O}$ and $\delta^{2} \mathrm{H}$ of water from the plateau and divide recharge zones. Inflow waters (NE and SE zones) are red and blue points displayed for context. Predicted meteoric source waters from LEL intercept with LMWL are colored numbers.

Figure 7. $\delta^{18} \mathrm{O}$ in waters from each zone plotted against sample elevation. Recharge limit line denotes elevation below which no significant recharge occurs; Houston (2009), Scheihing et al. (2018) and others have shown for this region the limit lies at $\sim 120 \mathrm{~mm}$ of precipitation per year (Figure 1). Blue shaded envelope represents the salar evaporite aquifer below the basin floor. Specific Conductivity ( $\mu \mathrm{S} / \mathrm{cm}$ ) of sample groupings in italics. Ellipses in (a), (b) and (c) indicate descriptive groupings discussed in text and blue arrows indicate general hydrochemical evolutionary pathways. Dashed arc in (d) indicates the predicted trend of isotopic evolution in a river system. Water types and locations are labeled in legend (Spr.=Spring water).

750 Figure 8. Conceptual model of the Salar de Atacama regional groundwater system, major 751 mechanisms governing the contemporary hydrologic system and their relative influence 
(adapted from Corenthal et al. 2016). In plan view (a), solid light blue arrows represent the distribution of modern meteoric inputs and their signatures, the brown dashed line denotes a major orographic barrier to precipitation east of Miñiques and Miscanti lakes. Solid blue arrows represent inflows of modern recharge, green dashed arrows are major inputs of paleogroundwater, red dashed arrows show hypothesized influx of solute-rich fluid. (b) Crosssectional view of the SE zone shows the distribution and relative importance of these hydrological mechanisms. Blue lines are estimated position of the modern water table, green is the LGM water table and the corresponding flow paths of modern and fossil groundwater, red is solute-rich influx.

\section{Table Captions:}

Table 1. Calculations of transit time estimates assuming piston flow and a decay constant. The $\mathrm{High}$ elevation lake water ${ }^{3} \mathrm{H}$ value and modern meteoric water are used as input ${ }^{3} \mathrm{H}$ values. These input values were decayed and seepage velocities $(\mathrm{v})$ estimated with aquifer properties ( $\mathrm{K}$ $\& \theta$ ) from Houston (2007) and a plausible range of values. Velocities were calculated by piston flow transit times, then the MRT of waters were estimated under these conditions.

\section{References}

Allmendinger, R. W., Jordan, T. E., Kay, S. M., \& Isacks, B. L. (1997). The Evolution of The Altiplano-Puna Plateau of the Central Andes. Annual Review of Earth and Planetary Sciences, 25(1), 139-174. https://doi.org/10.1146/annurev.earth.25.1.139

Ammann, C., Jenny, B., Kammer, K., \& Messerli, B. (2001). Late quaternary glacier response to humidity changes in the arid Andes of Chile (18-29 $\mathrm{S})$. Palaeogeography, Palaeoclimatology, Palaeoecology, 172(3-4), 313-326. https://doi.org/10.1016/S00310182(01)00306-6

Aravena, R. (1995). Isotope hydrology and geochemistry of northern Chile groundwaters. Bulletin - Institut Francais d'Etudes Andines, 24(3), 495-503.

Aravena, R., Suzuki, O., Peña, H., Pollastri, a., Fuenzalida, H., \& Grilli, a. (1999). Isotopic composition and origin of the precipitation in Northern Chile. Applied Geochemistry, 14(4), 411-422. https://doi.org/10.1016/S0883-2927(98)00067-5

Aron, F., González, G., Veloso, E., \& Cembrano, J. (2008). Architecture and style of compressive Neogene deformation in the eastern-southeastern border of the Salar de Atacama Basin (22 30'-24 15'S): A structural setting for the active volcanic arc of the Central Andes. In 7th International Symposium on Andean Geodynamics (ISAG 2008, Nice) (pp. 52-55)

Barnes, C. J., \& Allison, G. B. (1988). Tracing of water movement in the unsaturated zone using stable isotopes of hydrogen and oxygen. Journal of Hydrology, 100(1-3), 143-176. https://doi.org/10.1016/0022-1694(88)90184-9

Barnes, C. J., \& Walker, G. R. (1989). The distribution of deuterium and oxygen-18 during unsteady evaporation from a dry soil. Journal of Hydrology, 112(1-2), 55-67. https://doi.org/10.1016/0022-1694(89)90180-7

Belcher, W. R., Bedinger, M. S., Back, J. T., \& Sweetkind, D. S. (2009). Interbasin flow in the Great Basin with special reference to the southern Funeral Mountains and the source of Furnace Creek springs, Death Valley, California, U.S. Journal of Hydrology, 369(1-2), 30-43. https://doi.org/10.1016/j.jhydrol.2009.02.048

Bershaw, J., S. M. Penny, and C. N. Garzione (2012). Stable isotopes of modern water across the Himalaya and eastern Tibetan Plateau: Implications for estimates of paleoelevation and paleoclimate, J. Geophysical. Research, 117, D02110, doi:10.1029/2011JD016132 
Manuscript submitted for Review in Water Resources Research - September 19, 2019

Betancourt, J. L., Latorre, C., Rech, J. A., Quade, J., \& Rylander, K. A. (2000). A 22,000-year record of monsoonal precipitation from northern Chile's Atacama Desert. Science, 289(5484), 1542-1546

Beria, H., Larsen, J. R., Ceperley, N. C., Michelon, A., Vennemann, T., \& Schaefli, B. (2018). Understanding snow hydrological processes through the lens of stable water isotopes. Wiley Interdisciplinary Reviews: Water, 5(6), e1311. https://doi.org/10.1002/wat2.1311

Blard, P. H., Sylvestre, F., Tripati, A. K., Claude, C., Causse, C., Coudrain, A., ... Lavé, J. (2011). Lake highstands on the Altiplano (Tropical Andes) contemporaneous with Heinrich 1 and the Younger Dryas: New insights from 14C, U-Th dating and $\delta 18 \mathrm{O}$ of carbonates. Quaternary Science Reviews, 30(27-28), 3973-3989. https://doi.org/10.1016/j.quascirev.2011.11.001

Blodgett, T. a., J. D. Lenters, and B. L. Isacks (1997). Constraints on the origin of paleolake expansions in the Central Andes, Earth Interact., 1(1), 1-1, doi:10.1175/10873562(1997)001<0001: CotOoP $>2.0 . \mathrm{CO} ; 2$

Bobst, A. L., Lowenstein, T. K., Jordan, T. E., Godfrey, L. V., Ku, T. L., \& Luo, S. (2001). A 106 ka paleoclimate record from drill core of the Salar de Atacama, northern Chile. Palaeogeography, Palaeoclimatology, Palaeoecology, 173(1-2), 21-42. https://doi.org/10.1016/S0031-0182(01)00308-X

Boers, N., Bookhagen, B., Marwan, N., \& Kurths, J. (2016). Spatiotemporal characteristics and synchronization of extreme rainfall in South America with focus on the Andes Mountain range. Climate dynamics, 46(1-2), 601-617

Boschetti, T., Cortecci, G., Barbieri, M., \& Mussi, M. (2007). New and past geochemical data on fresh to brine waters of the Salar de Atacama and Andean Altiplano, northern Chile. Geofluids, 7(1), 33-50.

Boschetti, Cifuentes, Iacumin, \& Selmo. (2019). Local Meteoric Water Line of Northern Chile $\left(18^{\circ} \mathrm{S}-30^{\circ} \mathrm{S}\right)$ : An Application of Error-in-Variables Regression to the Oxygen and Hydrogen Stable Isotope Ratio of Precipitation. Water, 11(4), 791. doi:10.3390/w11040791

Boutt, D. F., Hynek, S. A., Munk, L. A., \& Corenthal, L. G. (2016). Rapid recharge of fresh water to the halite-hosted brine aquifer of Salar de Atacama, Chile. Hydrological Processes, 30(25), 4720-4740. https://doi.org/10.1002/hyp.10994

Boutt, D., Corenthal, L., Munk, L. A., \& Hynek, S. (2018). Imbalance in the modern hydrologic budget of topographic catchments along the western slope of the Andes (21-25 S). https://doi.org/10.31223/osf.io/p5tsq

Breitkreuz, C. (1995). The late Permian Peine and Cas Formations at the eastern margin of the Salar de Atacama, Northern Chile: stratigraphy, volcanic facies, and tectonics. Revista Geológica de Chile, 22(1), 3-23.

Burg, A., Zilberbrand, M., \& Yechieli, Y. (2013). Radiocarbon Variability in Groundwater in an Extremely Arid Zone-The Arava Valley, Israel. Radiocarbon, 55(2), 963-978. https://doi.org/10.1017/s0033822200058112

Cartwright, I., Cendón, D., Currell, M., \& Meredith, K. (2017). A review of radioactive isotopes and other residence time tracers in understanding groundwater recharge: Possibilities, challenges, and limitations. Journal of Hydrology, 555, 797-811. https://doi.org/10.1016/j.jhydrol.2017.10.053

Cervetto Sepúlveda, M. M. (2012). Caracterización hidrogeológica e hidrogeoquímica de las cuencas: Salar de Aguas calientes 2, Puntas negras, Laguna Tuyajto, Pampa Colorada, Pampa Las Tecas y Salar el Laco, II región de Chile.

Chaffaut I, Coudrain-Ribstein A, Michelot JL, Pouyaud B. (1998) Precipitations d'altitude du Nord-Chili, origine des sources de vapeur et donnees isotopiques. Bulletin de l'Institute Francais d etudes andine, 27, 367-84. 
Manuscript submitted for Review in Water Resources Research - September 19, 2019

882

883

884

885

886

887

888

889

890

891

892

893

894

895

896

897

Clark, I. D. 1., \& Fritz, P. 1. (1997). Environmental isotopes in hydrogeology. Boca Raton, FL: CRC Press/Lewis Publishers.

Clarke, W.B., Jenkins, W.J., Top, Z. (1976). Determination of Tritium by Mass Spectrometric Measurement of 3He. International Journal of Applied Radiation and Isotopes 27, 515 522.

Cook PG, Bohlke J-K. (2000). Determining timescales for groundwater flow and solute transport. In Environmental Tracers in Subsurface Hydrology, Cook PG, Herczeg AL (eds). Kluwer Academic Publishers: Norwell, MA; 1-30.

Corenthal, L. G., Boutt, D. F., Hynek, S. A., \& Munk, L. A. (2016). Regional groundwater flow and accumulation of a massive evaporite deposit at the margin of the Chilean Altiplano. Geophysical Research Letters, 43(15), 8017-8025. https://doi.org/10.1002/2016GL070076

Cortecci, G., Boschetti, T., Mussi, M., Lameli, C. H., Mucchino, C., \& Barbieri, M. (2005). New chemical and original isotopic data on waters from El Tatio geothermal field, northern Chile. Geochemical Journal, 39(6), 547-571. https://doi.org/10.2343/geochemj.39.547

Currell, M., Gleeson, T., Dahlhaus, P. (2016). A New Assessment Framework for Transience in Hydrogeological Systems. Groundwater 54, 4-14. doi:10.1111/gwat.12300

DePaolo, D. J., M. E. Conrad, K. Maher, and G. W. Gee. 2004. Evaporation Effects on Oxygen and Hydrogen Isotopes in Deep Vadose Zone Pore Fluids at Hanford, Washington. Vadose Zone J. 3:220-232. doi:10.2136/vzj2004.2200

De Porras, M. E., Maldonado, A., De Pol-Holz, R., Latorre, C., \& Betancourt, J. L. (2017). Late Quaternary environmental dynamics in the Atacama Desert reconstructed from rodent midden pollen records. Journal of Quaternary Science, 32(6), 665-684. https://doi.org/10.1002/jqs.2980

DGA [Dirección General de Aguas] (2013), Análisis de la Oferta Hídrica del Salar de Atacama, Santiago, Chile.

Draxler, R. R., \& G. D. Hess (1998). An overview of the HYSPLIT_4 modelling system for trajectories, dispersion and deposition, Aust. Meteorol. Mag., 47(4), 295-308.

Eugster, H. P. (1980). Geochemistry of evaporitic lacustrine deposits. Annual Review of Earth and Planetary Sciences: Volume 8, 35-63.

Favreau, G., Cappelaere, B., Massuel, S., Leblanc, M., Boucher, M., Boulain, N., \& Leduc, C. (2009). Land clearing, climate variability, and water resources increase in semiarid southwest Niger: A review. Water Resources Research, 45(7). https://doi.org/10.1029/2007WR006785

Fiorella, R. P., Poulsen, C. J., Pillco Zolá, R. S., Barnes, J. B., Tabor, C. R., \& Ehlers, T. A. (2015). Spatiotemporal variability of modern precipitation $\delta 180$ in the central Andes and implications for paleoclimate and paleoaltimetry estimates. Journal of Geophysical Research, 120(10), 4630-4656. https://doi.org/10.1002/2014JD022893

Fontes, J C, \& Molinari, J. (1975). Isotopic study of the upper watershed of the Rio Abancan (Province of Catamarca, Argentina). Rev. Geogr. Phys. Geol. Dyn.; (France); Journal Volume: 7:5

Fritz, P., Silva, H., Suzuki, O., \& Salati, E. (1979). Isotope hydrology in northern Chile. In Isotope hydrology 1978.

Fritz, P., Suzuki, O., Silva, C., \& Salati, E. (1981). Isotope hydrology of groundwaters in the Pampa del Tamarugal, Chile. Journal of Hydrology, 53(1-2), 161-184. https://doi.org/10.1016/0022-1694(81)90043-3

Fritz, S. C., P. a. Baker, T. K. Lowenstein, G. O. Seltzer, C. a. Rigsby, G. S. Dwyer, P. M. Tapia, K. K. Arnold, T. L. Ku, and S. Luo (2004). Hydrologic variation during the last 170,000 years in the southern hemisphere tropics of South America, Quat. Res., 61(1), 95-104. doi: 10.1016/j.yqres.2003.08.007 
Manuscript submitted for Review in Water Resources Research - September 19, 2019

Gardeweg, M., \& Ramírez, C. F. (1987). La Pacana caldera and the Atana Ignimbrite - a major ash-flow and resurgent caldera complex in the Andes of northern Chile. Bulletin of Volcanology, 49(3), 547-566. https://doi.org/10.1007/BF01080449

Garreaud, R., M. Vuille, \& A. C. Clement (2003). The climate of the Altiplano: Observed current conditions and mechanisms of past changes, Palaeogeography, Palaeoclimatology, Palaeoecology., 194(1-3), 5-22, doi:10.1016/S0031-0182(03)00269-4.

Garreaud, R. D. (2009). The Andes climate and weather. Advances in Geosciences, 22, 3-11. https://doi.org/10.5194/adgeo-22-3-2009

Gasse, F. (2000). Hydrological changes in the African tropics since the Last Glacial Maximum. In Quaternary Science Reviews (Vol. 19, pp. 189-211). https://doi.org/10.1016/S02773791(99)00061-X

Ge, J., Chen, J., Ge, L., Wang, T., Wang, C., \& Chen, Y. (2016). Isotopic and hydrochemical evidence of groundwater recharge in the Hopq Desert, NW China. Journal of Radioanalytical and Nuclear Chemistry, 310(2), 761-775. https://doi.org/10.1007/s10967016-4856-8

Gleeson, T., L. Marklund, L. Smith, and A. H. Manning (2011), Classifying the water table at regional to continental scales, Geophys. Res. Lett., 38, L05401, doi:10.1029/ 2010 GL046427.

Gleeson, T., Wada, Y., Bierkens, M.F.P., van Beek, L.P.H., (2012). Water balance of global aquifers revealed by groundwater footprint. Nature 488, 197-200. doi:10.1038/nature11295

Godfrey, L. V., Jordan, T. E., Lowenstein, T. K., \& Alonso, R. L. (2003). Stable isotope constraints on the transport of water to the Andes between $22^{\circ}$ and $26^{\circ} \mathrm{S}$ during the last glacial cycle. In Palaeogeography, Palaeoclimatology, Palaeoecology (Vol. 194, pp. 299317). Elsevier B.V. https://doi.org/10.1016/S0031-0182(03)00283-9

González, G., Cembrano, J., Aron, F., Veloso, E. E., \& Shyu, J. B. H. (2009). Coeval compressional deformation and volcanism in the central Andes, case studies from northern Chile $\left(23^{\circ} \mathrm{S}-24^{\circ} \mathrm{S}\right)$. Tectonics, 28(6). https://doi.org/10.1029/2009TC002538

Grosjean, M., Geyh, M. A., Messerli, B., \& Schotterer, U. (1995). Late-glacial and early Holocene lake sediments, ground-water formation and climate in the Atacama Altiplano 22-24ㅇ․ Journal of Paleolimnology, 14(3), 241-252. https://doi.org/10.1007/BF00682426.

Hartley, A. J., and G. Chong (2002), Late Pliocene age for the Atacama Desert: Implications for the desertification of western South America, Geology, 30(1), 43-46, doi:10.1130/00917613(2002)030<0043: LPAFTA>2.0.CO;2

Haitjema, H. M., \& S. Mitchell-Bruker (2005), Are water tables a subdued replica of the topography? Ground Water, 43, 781-786.

Herrera, C., Custodio, E., Chong, G., Lambán, L. J., Riquelme, R., Wilke, H., ... Lictevout, E. (2016). Groundwater flow in a closed basin with a saline shallow lake in a volcanic area: Laguna Tuyajto, northern Chilean Altiplano of the Andes. Science of the Total Environment, 541, 303-318. https://doi.org/10.1016/j.scitotenv.2015.09.060

Houston, J. (2002). Groundwater recharge through an alluvial fan in the Atacama Desert, northern Chile: mechanisms, magnitudes and causes. Hydrological processes, 16(15), 3019-3035.

Houston, J. (2006a). The great Atacama flood of 2001 and its implications for Andean hydrology. Hydrological Processes, 20(3), 591-610. https://doi.org/10.1002/hyp.5926

Houston, J. (2006b). Variability of precipitation in the Atacama Desert: its causes and hydrological impact. International Journal of Climatology, 26(15), 2181-2198.

Houston, J. (2007). Recharge to groundwater in the Turi Basin, northern Chile: An evaluation based on tritium and chloride mass balance techniques. Journal of Hydrology, 334(3-4), 534-544. https://doi.org/10.1016/j.jhydrol.2006.10.030 
Manuscript submitted for Review in Water Resources Research - September 19, 2019

Houston, J. (2009). A recharge model for high altitude, arid, Andean aquifers. Hydrological Processes, 23(16), 2383-2393. https://doi.org/10.1002/hyp.7350

Houston, J. \& Hart, D. (2004). Theoretical head decay in closed basin aquifers: an insight into fossil groundwater and recharge events in the Andes of northern Chile. Quarterly Journal of Engineering Geology and Hydrogeology 37, 131-139. doi:10.1144/1470-9236/04-007

Jasechko, S. (2016). Partitioning young and old groundwater with geochemical tracers. Chemical Geology, 427, 35-42. https://doi.org/10.1016/j.chemgeo.2016.02.012

Jasechko, S., S. J. Birks, T. Gleeson, Y. Wada, P. J. Fawcett, Z. D. Sharp, J. J. McDonnell, and J. M. Welker (2014), The pronounced seasonality of global groundwater recharge, Water Resour. Res., 50, 8845-8867, doi:10.1002/ 2014WR015809

Jasechko, S., Perrone, D., Befus, K. M., Bayani Cardenas, M., Ferguson, G., Gleeson, T., ... Kirchner, J. W. (2017). Global aquifers dominated by fossil groundwaters but wells vulnerable to modern contamination. Nature Geoscience, 10(6), 425-429. https://doi.org/10.1038/ngeo2943

Jordan, T. E., L. V. Godfrey, N. Munoz, R. N. Alonso, T. K. Lowenstein, G. D. Hoke, N. Peranginangin, B. L. Isacks, and L. Cathles (2002), Orogenic-scale ground water circulation in the Central Andes: evidence and consequences., 5th ISAG (International Symp. Andean Geodyn., 331-334.

Jordan, T. E., Nester, P. L., Blanco, N., Hoke, G. D., Dávila, F., \& Tomlinson, A. J. (2010). Uplift of the Altiplano-Puna plateau: A view from the west. Tectonics, 29(5). https://doi.org/10.1029/2010TC002661

Jordan, T., Lameli, C. H., Kirk-Lawlor, N., \& Godfrey, L. (2015). Architecture of the aquifers of the Calama Basin, Loa catchment basin, northern Chile. Geosphere, 11(5), 1438-1474. https://doi.org/10.1130/GES01176.1

Jordan, T. E., Herrera L., C., Godfrey, L. V., Colucci, S. J., Gamboa P., C., Urrutia M., J., ... Paul, J. F. (2019). Isotopic characteristics and paleoclimate implications of the extreme precipitation event of march 2015 in Northern Chile. Andean Geology, 46(1), 1-31. https://doi.org/10.5027/andgeov46n1-3087

Kafri, U., \& Yechieli, Y. (2012). The relationship between current and paleo groundwater baselevels. Quaternary International, 257, 83-96. https://doi.org/10.1016/j.quaint.2011.08.028

Kampf, S. K., \& Tyler, S. W. (2006). Spatial characterization of land surface energy fluxes and uncertainty estimation at the Salar de Atacama, Northern Chile. Advances in Water Resources, 29(2), 336-354. https://doi.org/10.1016/j.advwatres.2005.02.017

Kendall, C., \& Caldwell, E. A. (1998). Fundamentals of Isotope Geochemistry. In Isotope Tracers in Catchment Hydrology (pp. 51-86). Elsevier. https://doi.org/10.1016/b978-0-44481546-0.50009-4

Kendall, C., \& McDonnell, J. J. (1998). Isotope tracers in catchment hydrology. Isotope tracers in catchment hydrology. Elsevier Science B.V.

Kirchner, J. W. (2006). Getting the right answers for the right reasons: Linking measurements, analyses, and models to advance the science of hydrology. Water Resources Research, 42(3). https://doi.org/10.1029/2005WR004362

Koeniger, P., Gaj, M., Beyer, M., \& Himmelsbach, T. (2016). Review on soil water isotope-based groundwater recharge estimations. Hydrological Processes, 30(16), 2817-2834. https://doi.org/10.1002/hyp.10775

Kröpelin, S., Verschuren, D., Lézine, A. M., Eggermont, H., Cocquyt, C., Francus, P., ... Engstrom, D. R. (2008). Climate-driven ecosystem succession in the Sahara: The past 6000 years. Science, 320(5877), 765-768. https://doi.org/10.1126/science.1154913

Langenbrunner, B., Pritchard, M. S., Kooperman, G. J., \& Randerson, J. T. (2019). Why Does Amazon Precipitation Decrease When Tropical Forests Respond to Increasing CO2? Earth's Future, 7(4), 450-468. https://doi.org/10.1029/2018EF001026 
Manuscript submitted for Review in Water Resources Research - September 19, 2019

999

1000

1001

1002

1003

1004

1005

1006

1007

1008

1009

1010

1011

1012

1013

1014

1015

1016

1017

1018

1019

1020

1021

1022

1023

1024

1025

1026

1027

1028

1029

1030

1031

1032

1033

1034

1035

1036

1037

1038

1039

1040

1041

1042

1043

1044

1045

1046

1047

Landwehr, J. M., \& Coplen, T. B. (2006). Line-conditioned excess: a new method for characterizing stable hydrogen and oxygen isotope ratios in hydrologic systems. International conference on isotopes in environmental studies (pp. 132-135).

Latorre, C., Betancourt, J. L., Rylander, K. A., Quade, J., \& Matthei, O. (2003). A vegetation history from the arid prepuna of northern Chile $\left(22-23^{\circ} \mathrm{S}\right)$ over the last 13500 years. In Palaeogeography, Palaeoclimatology, Palaeoecology (Vol. 194, pp. 223-246). Elsevier B.V. https://doi.org/10.1016/S0031-0182(03)00279-7

Lindsey, B.D., Jurgens, B.C., and Belitz, K. (2019). Tritium as an indicator of modern, mixed, and premodern groundwater age: U.S. Geological Survey Scientific Investigations Report 2019-5090, 18 p., https://doi.org/10.3133/sir20195090

Love, A. H., \& Zdon, A. (2018). Use of radiocarbon ages to narrow groundwater recharge estimates in the southeastern Mojave Desert, USA. Hydrology, 5(3). https://doi.org/10.3390/hydrology5030051

Lowenstein, T. K., Hein, M. C., Bobst, A. L., Jordan, T. E., Ku, T.-L., \& Luo, S. (2003). An Assessment of Stratigraphic Completeness in Climate-Sensitive Closed-Basin Lake Sediments: Salar de Atacama, Chile. Journal of Sedimentary Research, 73(1), 91-104. https://doi.org/10.1306/061002730091

Lucas, L.L., Unterweger (2000). Comprehensive Review and Critical Evaluation of the Half-Life of Tritium. Journal of Research of the National Institute of Standards and Technology 105, $541-549$.

Magaritz, M., Aravena, R., Peña, H., Suzuki, O., \& Grilli, A. (1989). Water chemistry and isotope study of streams and springs in northern Chile. Journal of Hydrology, 108(C), 323-341. https://doi.org/10.1016/0022-1694(89)90292-8

Magilligan, F. J., Goldstein, P. S., Fisher, G. B., Bostick, B. C., \& Manners, R. B. (2008). Late Quaternary hydroclimatology of a hyper-arid Andean watershed: Climate change, floods, and hydrologic responses to the El Niño-Southern Oscillation in the Atacama Desert. Geomorphology, 101(1-2), 14-32. https://doi.org/10.1016/j.geomorph.2008.05.025

Mather, A. E., \& Hartley, A. (2005). Flow events on a hyper-arid alluvial fan: Quebrada Tambores, Salar de Atacama, northern Chile. Geological Society Special Publication, 251, 9-24. https://doi.org/10.1144/GSL.SP.2005.251.01.02

Maxey, G. B. (1968). Hydrogeology of Desert Basins. Groundwater, 6(5), 10-22. https://doi.org/10.1111/j.1745-6584.1968.tb01660.x

McKnight, Sarah, (2019). "The Climatic and Hydrostratigraphic Controls on Brine-to-Freshwater Interface Dynamics in Hyperarid Climates: A 2-D Parametric Groundwater Modeling Study". Masters Theses. 785.https://scholarworks.umass.edu/masters_theses_2/785

Meijer, A. \& Kwicklis, E. (2000). Geochemical and Isotopic Constraints on Ground-Water Flow Directions, Mixing and Recharge at Yucca Mountain, Nevada. United States. doi:10.2172/883407

Müller, T., Osenbrück, K., Strauch, G., Pavetich, S., Al-Mashaikhi, K. S., Herb, C., ... Sanford, W. (2016). Use of multiple age tracers to estimate groundwater residence times and longterm recharge rates in arid southern Oman. Applied Geochemistry, 74, 67-83. https://doi.org/10.1016/j.apgeochem.2016.08.012

Munk, L. A., Boutt, D. F., Hynek, S. A., \& Moran, B. J. (2018). Hydrogeochemical fluxes and processes contributing to the formation of lithium-enriched brines in a hyper-arid continental basin. Chemical Geology, 493, 37-57. https://doi.org/10.1016/j.chemgeo.2018.05.013

Ortiz, C., Aravena, R., Briones, E., Suárez, F., Tore, C., \& Muñoz, J. F. (2014). Sources of surface water for the Soncor ecosystem, Salar de Atacama basin, northern Chile. Hydrological Sciences Journal, 59(2), 336-350. 
Manuscript submitted for Review in Water Resources Research - September 19, 2019

1048

1049

1050

1051

1052

1053

1054

1055

1056

1057

1058

1059

1060

1061

1062

1063

1064

1065

1066

1067

1068

1069

1070

1071

1072

1073

1074

1075

1076

1077

1078

1079

1080

1081

1082

1083

1084

1085

1086

1087

1088

1089

1090

1091

1092

1093

1094

1095

1096

1097

Pascale, S., Carvalho, L. M. V., Adams, D. K., Castro, C. L., \& Cavalcanti, I. F. A. (2019). Current and Future Variations of the Monsoons of the Americas in a Warming Climate. Current Climate Change Reports. Springer. https://doi.org/10.1007/s40641-019-00135-w

Peralta Arnold, Y., Cabassi, J., Tassi, F., Caffe, P. J., \& Vaselli, O. (2017). Fluid geochemistry of a deep-seated geothermal resource in the Puna plateau (Jujuy Province, Argentina). Journal of Volcanology and Geothermal Research, 338, 121-134. https://doi.org/10.1016/j.jvolgeores.2017.03.030

Pérez-Fodich, A., Reich, M., Álvarez, F., Snyder, G. T., Schoenberg, R., Vargas, G., ... \& Fehn, U. (2014). Climate change and tectonic uplift triggered the formation of the Atacama Desert's giant nitrate deposits. Geology, 42(3), 251-254.

Pingel, H., Alonso, R. N., Altenberger, U., Cottle, J., \& Strecker, M. R. (2019). Miocene to Quaternary basin evolution at the southeastern Andean Plateau (Puna) margin (ca. $24^{\circ} \mathrm{S}$ lat, Northwestern Argentina). Basin Research, 31(4), 808-826. https://doi.org/10.1111/bre.12346

Placzek, C., Quade, J., \& Patchett, P. J. (2006). Geochronology and stratigraphy of late Pleistocene lake cycles on the southern Bolivian Altiplano: Implications for causes of tropical climate change. Bulletin of the Geological Society of America, 118(5-6), 515532. https://doi.org/10.1130/B25770.1

Placzek, C., Quade, J., Betancourt, J. L., Patchett, P. J., Rech, J. A., Latorre, C., ... English, N. B. (2009). CLIMATE IN THE DRY CENTRAL ANDES OVER GEOLOGIC, MILLENNIAL, AND INTERANNUAL TIMESCALES. Annals of the Missouri Botanical Garden, 96(3), 386-397. https://doi.org/10.3417/2008019

Placzek, C. J., Quade, J., \& Patchett, P. J. (2013). A 130ka reconstruction of rainfall on the Bolivian Altiplano. Earth and Planetary Science Letters, 363, 97-108. https://doi.org/10.1016/j.eps1.2012.12.017

Quade, J., Rech, J. A., Betancourt, J. L., Latorre, C., Quade, B., Rylander, K. A., \& Fisher, T. (2008). Paleowetlands and regional climate change in the central Atacama Desert, northern Chile. Quaternary Research, 69(3), 343-360.

Ramirez, C., and M. Gardeweg (1982). Carta Geologica de Chile, escala 1:250000, Hoja Toconao, Region de Antofagasta, Chile No. 54, Santiago, Chile.

Rech, J. A., Quade, J., \& Betancourt, J. L. (2002). Late Quaternary paleohydrology of the central Atacama Desert (lat $22^{\circ}-24^{\circ} \mathrm{S}$ ), Chile. Bulletin of the Geological Society of America, 114(3), 334-348. https://doi.org/10.1130/0016-7606(2002)114<0334:LQPOTC >2.0.CO;2

Rech, J. A., Pigati, J. S., Quade, J., \& Betancourt, J. L. (2003). Re-evaluation of mid-Holocene deposits at Quebrada Puripica, northern Chile. In Paleogeography, Paleoclimatology, Paleoecology (Vol. 194, pp. 207-222). https://doi.org/10.1016/S0031-0182(03)00278-5

Rech, J. A., Currie, B. S., Jordan, T. E., Riquelme, R., Lehmann, S. B., Kirk-Lawlor, N. E., ... Gooley, J. T. (2019). Massive middle Miocene gypsic paleosols in the Atacama Desert and the formation of the Central Andean rain-shadow. Earth and Planetary Science Letters, 506, 184-194. https://doi.org/10.1016/j.epsl.2018.10.040

Reutter, K. J., Charrier, R., Götze, H. J., Schurr, B., Wigger, P., Scheuber, E., ... \& Chong, G. (2006). The Salar de Atacama Basin: a subsiding block within the western edge of the Altiplano-Puna Plateau. In the Andes (pp. 303-325). Springer Berlin Heidelberg.

Risacher, F., Alonso, H., Salazar, C. (1999). Geoquímica de aguas en cuencas cerradas: I, II y III Regiones-Chile. 1. Ministerio de Obras Públicas, pp. 209.

Risacher, F., Alonso, H., \& Salazar, C. (2003). The origin of brines and salts in Chilean salars: a hydrochemical review. Earth-Science Reviews, 63(3), 249-293.

Rissmann, C., Leybourne, M., Benn, C., \& Christenson, B. (2015). The origin of solutes within the groundwaters of a high Andean aquifer. Chemical Geology, 396, 164-181.

https://doi.org/10.1016/j.chemgeo.2014.11.029 
Manuscript submitted for Review in Water Resources Research - September 19, 2019

1098

1099

1100

1101

1102

1103

1104

1105

1106

1107

1108

1109

1110

1111

1112

1113

1114

1115

1116

1117

1118

1119

1120

1121

1122

1123

1124

1125

1126

1127

1128

1129

1130

1131

1132

1133

1134

1135

1136

1137

1138

1139

1140

1141

1142

1143

1144

1145

1146

1147

1148

Rohrmann, A., Strecker, M. R., Bookhagen, B., Mulch, A., Sachse, D., Pingel, H., ... Montero, C. (2014). Can stable isotopes ride out the storms? The role of convection for water isotopes in models, records, and paleoaltimetry studies in the central Andes. Earth and Planetary Science Letters, 407, 187-195. https://doi.org/10.1016/j.eps1.2014.09.021

Rosen, M. R. (1994). The importance of groundwater in playas: A review of playa classifications and the sedimentology and hydrology of playas. Special Paper of the Geological Society of America, 289, 1-18. https://doi.org/10.1130/SPE289-p1

Sáez, A., Godfrey, L. V., Herrera, C., Chong, G., \& Pueyo, J. J. (2016). Timing of wet episodes in Atacama Desert over the last $15 \mathrm{ka}$. The Groundwater Discharge Deposits (GWD) from Domeyko Range at $25^{\circ} \mathrm{S}$. Quaternary Science Reviews, 145, 82-93. https://doi.org/10.1016/j.quascirev.2016.05.036

Scanlon, B. R., Keese, K. E., Flint, A. L., Flint, L. E., Gaye, C. B., Edmunds, W. M., \& Simmers, I. (2006). Global synthesis of groundwater recharge in semiarid and arid regions. Hydrological Processes, 20(15), 3335-3370. https://doi.org/10.1002/hyp.6335

Scheihing, K. W., Moya, C. E., Struck, U., Lictevout, E., \& Tröger, U. (2018). Reassessing hydrological processes that control stable Isotope Tracers in groundwater of the Atacama Desert (Northern Chile). Hydrology, 5(1). https://doi.org/10.3390/hydrology5010003

Skrzypek, G., Dogramaci, S., Rouillard, A., \& Grierson, P. F. (2016). Groundwater seepage controls salinity in a hydrologically terminal basin of semi-arid northwest Australia. Journal of Hydrology, 542, 627-636. https://doi.org/10.1016/j.jhydrol.2016.09.033

Stewart, M. K., Morgenstern, U., Gusyev, M. A., \& Małoszewski, P. (2017). Aggregation effects on tritium-based mean transit times and young water fractions in spatially heterogeneous catchments and groundwater systems. Hydrology and Earth System Sciences, 21(9), 4615-4627. https://doi.org/10.5194/hess-21-4615-2017

Stigter, E. E., Litt, M., Steiner, J. F., Bonekamp, P. N. J., Shea, J. M., Bierkens, M. F. P., \& Immerzeel, W. W. (2018). The Importance of Snow Sublimation on a Himalayan Glacier. Frontiers in Earth Science, 6. https://doi.org/10.3389/feart.2018.00108

Strecker, M. R., Alonso, R. N., Bookhagen, B., Carrapa, B., Hilley, G. E., Sobel, E. R., \& Trauth, M. H. (2007). Tectonics and Climate of the Southern Central Andes. Annual Review of Earth and Planetary Sciences, 35(1), 747-787. https://doi.org/10.1146/annurev.earth.35.031306.140158

Tóth, J. (1963). A theoretical analysis of groundwater flow in small drainage basins. Journal of Geophysical Research, 68(16), 4795-4812. https://doi.org/10.1029/jz068i016p04795

Tsujimura, M., Abe, Y., Tanaka, T., Shimada, J., Higuchi, S., Yamanaka, T., ... Oyunbaatar, D. (2007). Stable isotopic and geochemical characteristics of groundwater in Kherlen River basin, a semi-arid region in eastern Mongolia. Journal of Hydrology, 333(1), 47-57. https://doi.org/10.1016/j.jhydrol.2006.07.026

Tyler, S.W., Kranz, S., Parlange, M.B., Albertson, J., Katul, G.G., Cochran, G.F., Lyles, B.A., Holder, G. (1997). Estimation of groundwater evaporation and salt flux from Owens Lake, California, USA. Journal Hydrology 200, 110-135.

Walvoord, M. A., Plummer, M. A., Phillips, F. M., \& Wolfsberg, A. V. (2002). Deep arid system hydrodynamics 1 . Equilibrium states and response times in thick desert vadose zones. Water Resources Research, 38(12), 44-1-44-15. https://doi.org/10.1029/2001WR000824

Ward, K. M., Zandt, G., Beck, S. L., Christensen, D. H., \& McFarlin, H. (2014). Seismic imaging of the magmatic underpinnings beneath the Altiplano-Puna volcanic complex from the joint inversion of surface wave dispersion and receiver functions. Earth and Planetary Science Letters, 404, 43-53. https://doi.org/10.1016/j.epsl.2014.07.022

Ward, D. J., Cesta, J. M., Galewsky, J., \& Sagredo, E. (2015). Late Pleistocene glaciations of the arid subtropical Andes and new results from the Chajnantor Plateau, northern Chile.

Quaternary Science Reviews, 128, 98-116.

https://doi.org/10.1016/j.quascirev.2015.09.022 
Manuscript submitted for Review in Water Resources Research - September 19, 2019

WMC [Water Management Consultants Ltda.] (2007). Analisis de la relacion entre las aguas subterraneas del Proyecto Pampa Colorada, las vertientes y del margen este del Salar de Atacama y las Lagunas Miscanti y Minique, Informe III Final, Santiago, Chile.

Wheater, H., Sorooshian, S., \& Sharma, K. D. (2007). Hydrological modelling in arid and semiarid areas. Hydrological Modelling in Arid and Semi-Arid Areas (Vol. 9780521869188, pp. 1-212). Cambridge University Press. https://doi.org/10.1017/CBO9780511535734

Wilson, J. L., \& Guan, H. (2013). Mountain-Block Hydrology and Mountain-Front Recharge. In Groundwater Recharge in a Desert Environment: The Southwestern United States (Vol. 9, pp. 113-137). American Geophysical Union. https://doi.org/10.1029/009WSA08

Wood, C., Cook, P. G., \& Harrington, G. A. (2015). Vertical carbon-14 profiles for resolving spatial variability in recharge in arid environments. Journal of Hydrology, 520, 134-142. https://doi.org/10.1016/j.jhydrol.2014.11.044

Van Beek, L.P.H., Wada, Y., Bierkens, M.F.P. (2011). Global monthly water stress: 1. Water balance and water availability. Water Resources Research 47, W07517. doi:10.1029/2010wr009791

Vuille, M., \& Ammann, C. (1997). Regional Snowfall Patterns in the High, Arid Andes. In Climatic Change at High Elevation Sites (pp. 181-191). Dordrecht: Springer Netherlands. https://doi.org/10.1007/978-94-015-8905-5_10

Zimmerman, U., D. Ehhalt, and K.O. Munnich. (1967). Soil water movement and evapotranspiration: Changes in the isotopic composition of the water. Paper presented at International Atomic Energy Agency Symposium on Isotopes in Hydrology. Int. Atomic Energy Agency, Vienna, Austria. 